\title{
Kişisel Gelişim Olanaklarına İlișkin Kişi-Kurum Değer Uyumunun İşe Adanmışlık ile İlişkisi: Çalışma Süresinin Rolü
}

\author{
Mehmet Peker \\ Ege Üniversitesi
}

\author{
Nevra Cem Ersoy \\ İzmir Ekonomi Üniversitesi
}

\author{
Muazzez Deniz Giray \\ Bağımsız Araştırmacı
}

\begin{abstract}
Özet
Bu çalışma kurumun sunduğu kişisel gelişim olanaklarına ilişkin çalışanın deneyimlediği değer uyumunun işe adanmışlık üzerindeki etkisini incelemiştir. İş Talepleri ve Kaynakları Modeli ile Tükenmişliğin ve Adanmışlığın Aracılık Modeli'nden hareketle kurumun sunduğu kişisel gelişim olanaklarına ilişkin değer uyumunun işe adanmışlık ile eğrisel bir ilişki göstereceği ve Çekim-Seçim-Yıpranma Modeli'nden hareketle kurumdaki çalışma süresinin bu ilişkide düzenleyici rol oynayacağı ileri sürülmüştür. Çalışma verisi 204 beyaz yaka çalışandan toplanmış ve fark değişkeni oluşturularak gerçekleştirilen polinom regresyon analizi ve tepki yüzey analizinin sonuçları değer uyumu ile işe adanmışlık arasında eğrisel bir ilişki bulunduğunu göstermiştir. Kurumdaki çalışma süresi ise bu ilişkide düzenleyici rol oynamıştır. Kurumdaki çalışma süresi daha az olan çalışanların işe adanmışlık düzeyleri değer uyumundan daha fazla etkilenmiştir. Çalışma sonuçları, iş kaynaklarının yanı sıra bu kaynaklara ilişkin değer uyumunun önemini ve kurumdaki çalışma süresinin dikkate alınması gerekliliğini vurgulaması yönüyle önemlidir.
\end{abstract}

Anahtar kelimeler: İşe adanmışlık, değer uyumu, kişisel gelişim olanakları, çalışma süresi

\begin{abstract}
This study examines the effect of person-organization value congruence regarding opportunities for personal development provided by the organization on work engagement. A curvilinear relationship between value congruence regarding opportunities for personal development and work engagement was hypothesized, building on the job demands-resources, mediation of burnout and engagement, and attraction-selection-attrition models. It was also hypothesized that organizational tenure would moderate the curvilinear relationship between value congruence and work engagement. Data were collected from 204 white-collar employees. Both difference score-based polynomial regression analysis and response surface analysis results provided support for the curvilinear value congruence - work engagement relationship. Moreover, as expected, organizational tenure moderated this relationship: The effect of value congruence on work engagement was stronger for employees with shorter tenure compared to those with longer tenure. Findings not only highlight the importance of value congruence regarding opportunities for personal development in work engagement, but also the role of tenure in this relationship.
\end{abstract}

Keywords: Work engagement, value congruence, opportunities for personal development, tenure

Yazışma Adresi: Arş. Gör. Mehmet Peker, Ege Üniversitesi Edebiyat Fakültesi Psikoloji Bölümü 35040 Bornova / İzmir

E-posta: mehmet.peker@ege.edu.tr

Gönderim Tarihi: 08.09.2018

Kabul Tarihi: 02.05.2019 
Pozitif psikoloji ve kavramlarının örgütsel davranış yazınına konu olmaya başlamasıyla birlikte işe adanmışlık da hem araştırmacılar hem de kurumlarda çalışan uzmanlar tarafından ilgi görmeye başlamıştır (Bakker, Schaufeli, Leiter ve Taris, 2008; Knight, Patterson ve Dawson, 2017). İşe adanmışlık, işe karşı duyulan yüksek düzeyde ilgi, heves ve özdeşimi içeren, duygusal ve motivasyonel açıdan işle ilgili iyi hissetme durumu olarak tanımlanabilir (Leiter ve Bakker, 2010; Schaufeli, Salanova, González-Romá ve Bakker, 2002). Yapılan araştırmalar, işe adanmışlığa olan ilginin sadece popüler bir kavram olmasından ibaret olmadığını, işe adanmışlığın önemli örgütsel çıktılarla ilişkili olduğunu göstermektedir. Örneğin, işe adanmışlık düzeyleri yüksek çalışanların daha yüksek iş performansı sergiledikleri (Kim, Kolb ve Kim, 2013; Rich, Lepine ve Crawford, 2010), daha yüksek düzeyde örgütsel vatandaşlık davranışı bildirdikleri (Babcock-Roberson ve Strickland, 2010; Halbesleben ve Wheeler, 2008), iyilik hali düzeylerinin daha yüksek olduğu (Schaufeli, Taris ve Van Rhenen, 2008), daha olumlu müşteri geri bildirimleri aldıkları (Salanova, Agut ve Peiró, 2005) ve işten ayrılma niyeti düzeylerinin daha düşük olduğu (Halbesleben ve Wheeler, 2008) görülmüştür. Buna ek olarak, çalışanların deneyimledikleri işe adanmışlığın sadece çalışan ya da kurumlar için değil, çalışanların aileleri ve çalışma arkadaşları için de pozitif etkileri olduğunu gösteren çalışmalar mevcuttur. Örneğin, yaptıkları çalışmada Bakker ve Xanthopoulou (2009) işe adanmışlık deneyimleyen çalışma arkadaşlarının özellikle iletişimlerinin sık olduğu günlerde bu deneyimlerini birbirlerine aktardıklarını ve daha yüksek iş performansı sergilediklerini göstermişlerdir. Culbertson, Mills ve Fullagar (2012) ise iş günü içinde deneyimlenen işe adanmışlığın pozitif etkilerinin günün akşamındaki aile etkileşimine aktarıldığını tespit etmişlerdir. Çalışanlar ve kurumlar için bu denli önemli faydaları olan işe adanmışlığı etkileyen faktörlerin açığa çıkarılması önem arz etmektedir.

İşe adanmışlığın öncüllerini belirlemeyi hedefleyen çalışmalara en fazla konu olan kavramlardan birisinin iş talepleri ve kaynakları olduğu söylenebilir. İş Talepleri ve Kaynakları Modeli'ne göre, çalışma ortamının özellikleri temelde iki kategoriye ayrılmaktadır. Bunlardan iş talepleri, işin çalışandan belirli bir fiziksel ya da psikolojik kaynak talep eden özellikleri iken, iş kaynakları iş taleplerinin etkilerini azaltan ya da çalışanın işini etkili bir biçimde yapmasını kolaylaştıran iş özellikleridir (Demerouti, Bakker, Nachreiner ve Schaufeli, 2001). İş talepleri ve kaynakları ile işe adanmışlık ilişkisini inceleyen çalışmalar, çalışanın yerine getirmesi beklenen taleplerin ve çalışana sunulan kaynakların işe adanmışlığ önemli ölçüde etkileyen yakınsak öncüllerden olduğunu göstermişlerdir (Bakker ve Bal, 2010; Halbesleben,
2010; Mauno, Kinnunen ve Ruokolainen, 2007; Schaufeli ve Bakker, 2004). Fakat bu çalışmalar incelendiğinde iş talepleri ve kaynaklarının bildirim düzeylerinin işe adanmışlık üzerindeki doğrudan etkilerinin incelendiği görülmektedir. Buna karşın çalışanın özellikle belirli bir iş kaynağına atfettiği değer ile kurumun bu iş kaynağını ne derecede sağladığına ilişkin uyumun etkisini inceleyen araştırılmalar kısıtlıdır. Oysaki işe adanmışlık kavramını ortaya atan ilk araştırmacılardan olan Kahn (1990), işe adanmışlı̆̆ 1 etkileyen önemli faktörlerden birisinin çalışanın kişisel değerlerinin kurum tarafından da paylaşıldığına dair algısı olduğunu belirtmektedir. Bu bağlamda çalışanların belirgin bir iş kaynağına atfettiği değerler ve kurumun bu iş kaynağını ne derece sağladığına ilişkin uyumu araştırmak son derece önemlidir.

Yukarıda bahsedilenlerden hareketle çalışmanın iki temel amacı vardır. Birinci amaç, Tükenmişliğin ve Adanmışlığın Aracılık Modeli'yle (Leiter ve Maslach, 2005) paralel olarak çalışanın kişisel gelişimine verdiği değer ile bir iş kaynağı olan kurumun sunduğu kişisel gelişim olanaklarının uyumluluğu ve uyumsuzluğunun ișe adanmışlık ile ilişkisini incelemektir. Araştırmanın ikinci amacı, Çekim Seçim Yıpranma Modeli'nin (Attraction Selection Attrition Model; Schneider, 1987; Schneider, Goldstein ve Smith, 1995) desteğiyle bahsi geçen uyum durumunun işe adanmışlik üzerindeki etkisinin yeni ve deneyimli çalışanlar için farklı olup olmadığını araştırmaktır (bkz. Şekil 1).

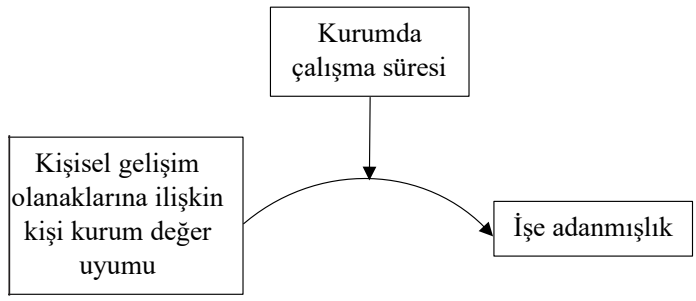

\section{Şekil 1. Hipotez Edilen Araştırma Modeli}

Araştırma, çalışanların işe adanmışlık düzeylerini artırmaya yönelik yeni bir faktörü açığa çıkarmayı hedeflediği için hem araştırmacılar hem de uygulamacılar için önemlidir. Yazındaki diğer çalışmaların büyük bir bölümü iş talepleri ve kaynaklarının işe adanmışlık ilişkisi üzerindeki doğrudan etkisini araştırmıştır. Fakat bu araştırma, yazındaki araştırmalardan farklı olarak çalışanlara kurumlar tarafından sunulan bir iş kaynağı olan kişisel gelişim olanaklarına ilişkin uyumunun etkisini araştırmayı hedeflemektedir. Bunun yanı sıra çalışma, kişisel gelişim olanaklarının işe adanmışlık üzerindeki etkisinin kurumda çalışma süresi az ve çok olan çalışanlar için de- 
ğişip değişmediğini de inceleyecektir. İşe adanmışlığın özellikle hangi çalışanlar üzerinde etkili olduğunu ortaya çıkarmak hem araştırmacılar hem de uygulamacılar için son derece yol gösterici olacaktır.

\section{Kurumun Sunduğu Kişisel Gelişim Olanaklarına İlişkin Kişi Kurum Değer Uyumu ile İşe Adanmışlık İlişkisi}

Schaufeli ve arkadaşları (2002) işe adanmışlığg dinçlik, işe bağlanma ve işe yoğunlaşma bileşenlerinden oluşan bir kavram olarak tanımlamışlardır. Dinçlik, çalışma sırasında sergilenen zihinsel dayanıklılık ve yüksek enerjiyle, işe bağlanma işe dair deneyimlenen anlamlılık, ilham, heyecan ve gururla, işe yoğunlaşma ise işe tam anlamıyla odaklanabilmeyle açıklanmıştır. İşe adanmışlık kavramının tanımına ilişkin farklı yaklaşımlar olsa da (örn., Kahn, 1990; Maslach ve Leiter, 1997) yüksek düzeydeki enerji ve işle olan güçlü özdeşim tüm yaklaşımlarda ortak olarak dile getirilen iki kavram olarak karşımıza çıkmaktadır. Bakker ve Demerouti (2017) iş kaynaklarının, iş taleplerinin üstesinden gelinebilmesi için çok önemli olduğunu belirtmiş ve işe adanmışlık deneyimi için iş yerinde yaşanan zorluklar ile baş etmeyi sağlayan kaynakların önemini vurgulamıştır. $\mathrm{Bu}$ özellikleri sebebiyle işe adanmışlığın, iş kaynaklar1 ile iş taleplerine kıyasla daha yüksek düzeyde ilişkili olabileceği öngörülmüştür. Christian, Garza ve Slaughter (2011) yaptıkları meta-analizde iş kaynaklarının iş taleplerine kıyasla işe adanmışlıkla daha yüksek düzeyde ilişkili olduğunu göstermişlerdir. İş kaynaklarının işe adanmışlığa olan etkisini boylamsal bir çalışma ile test eden Mauno ve arkadaşları (2007), daha yüksek iş kontrolü bildiren katılımcıların iki sene sonra alınan ölçümlerde daha yüksek işe adanmışlık düzeylerine sahip olduklarını saptamışlardır. Bu sonuçlar, işe adanmışlı̆̆ın iş özellikleri ile ilişkisinde iş kaynaklarının bir adım öne çıktığını göstermektedir.

İş kaynakları, çalışana görevlerini yerine getirmesinde yardımcı olan, iş taleplerinin fiziksel ya da psikolojik yüklerini azaltan ya da kişisel gelişimi ve öğrenmeyi destekleyen iş özellikleri olarak tanımlanabilir (Bakker ve Demerouti, 2007). Öz Belirleme Kuramı'ndan (Deci ve Ryan, 2002) da hareketle araştırmacılar iş kaynaklarının iki özelliği sebebiyle motivasyonu, dolayısıyla işe adanmışlığı artıracağını öngörmüşlerdir. İlk olarak iş kaynakları, iş talepleri ile baş etmeyi ve hedefleri yerine getirmeyi kolaylaştırmaktadır. Zorlukların az olduğu elverişli bir iş ortamı ise çalışanlar için daha cazip olmakta ve dışsal motivasyonu artırmaktadır. İkinci olarak ise iş kaynakları temel insan ihtiyaçlarından olan özerklik, ilişkisellik ve yeterlik doyumu sağlayarak içsel motivasyonu artırmaktadır (Bakker ve ark., 2008; Hakanen ve Roodt, 2010). Bu bilgiler iş kaynaklarının farklı süreçler aracılığıyla pozitif yönde etkiler sağladığına ilişkin ipuçları vermektedir. Bunların yanında çalışmalar, iş kaynaklarının işe adanmışlığın da dahil olduğu farklı çalışan çıktıları ile farklı büyüklüklerde ilişki örüntüleri gösterdiğini saptamışlardır (Halbesleben, 2010; Mauno ve ark., 2007). Tüm bunlar, iş kaynaklarının çalışanlar üzerinde pozitif yönde etkileri olsa da farklı yapılara ve etkilere sahip olduklarını, dolayısıyla belirli bir iş kaynağına yönelik etkinin incelenmesinden fayda sağlanabileceğini göstermektedir.

$\mathrm{Bu}$ araştırmada özellikle içsel motivasyonu artıran iş kaynaklarından olan kurumun sunduğu kişisel gelişim olanaklarına ilişkin değer uyumunun işe adanmışlıkla ilişkili olacağ1 öngörülmüştür. Bu öngörüye kuramsal destek Leiter ve Maslach'ın (2005) öne sürdüğü Tükenmişliğin ve Adanmışlığın Aracılık Modeli'nden gelmektedir. Bu model, iş özelliklerinin tükenmişliğe etkisinin açıklanmasında kişi-kurum uyumunun türlerinden olan değer uyumunu merkeze koymaktadır. Çalışanlar kültür, aile yaşantıları gibi birtakım etkilerle şekillenen değerlerinin kurumla uyumlu olup olmadığına, kurumun eylemlerinin öne çıkardığı değerlerle örtüşüp örtüşmediğine de dayanarak karar vermektedirler (Leiter ve Maslach, 2010). Kurumları ile kendi değerlerinin uyumlu oldugu kanısına varmaları durumunda motivasyonları ve işe katılımları artmaktadır. Değer uyumu olmadığında ise kişisel ve kurumsal değerler arasındaki çatışma işe adanmışlığı azaltmaktadır (Leiter ve Maslach, 2004). Araştırmacılar modellerinde iş kontrolü, ödüller, adalet gibi öğelerden oluşan bir takım iş özelliklerinin değer uyumu aracılığı ile tükenmişliğin üç alt boyutunu (duygusal tükenme, duyarsızlaşma ve kişisel başarı azlığı) etkilediği bir yapıyı öğrenciler ve hastane çalışanlarından oluşan örneklemlerde sınamışlardır. Sonuçlarda iş özelliklerinin tükenmişlikle değer uyumu aracılığı ile ilişkili olduğu saptanmıştır (Leiter ve Maslach, 2005). Bunun dışında modele destek sunabilecek az da olsa araştırma mevcuttur. Örneğin, Rich ve arkadaşları (2010) kişinin kurum hakkında sahip olduğu genel değer uyumunun işe adanmışlık ile ilişkili olduğunu göstermişlerdir. Leiter ve Bakker (2010) işe adanmışlığın, kişisel ve kurumsal değerlerin uyumlu olduğu bir bağlamdan pozitif yönde etkileneceğini dile getirmişlerdir. Kahn (1992) ise çalışanların kurumda gözlemlediği değerlerle benlik imajları açısından önemli gördükleri değerler arasında bir uyum söz konusu olduğunda işlerini daha çekici ve anlam yüklü göreceklerini ve daha fazla işe adanmışlık deneyimleyeceklerini ifade etmiştir.

$\mathrm{Bu}$ çalışmanın kuramsal altyapısı oluşturulurken tükenmişliğin ve adanmışlığın aracılık modeli temel alınmakla birlikte, bu modele kıyasla çalışmada çeşitli kavramsallaştırma ve yöntem farklılıkları mevcuttur. İlk fark değer uyumunun ölçülme biçimine ilișkindir. Leiter ve Maslach (2005), değer uyumunu çalışanların uyum 
düzeyinin öz bildirim yoluyla doğrudan elde edildiği algılanan uyum değerlendirmeleri biçiminde ölçmektedir (örnek madde: "Benim değer ve ideallerim kurumumun değer ve idealleri ile örtüşür"). Bu yöntemin güçlü tarafları olsa da kişi ve çevre temelli etkilerin birbirine karışması, diğer ölçümlerle beraber kullanıldığında tutarlı olma yanlılığına sebep olabilmesi gibi zayıf tarafları da olduğu dile getirilmiştir (Edwards, 1991; Kristof, 1996). Bu nedenle, bu çalışmada dolaylı bir değer uyumu tanımlaması tercih edilmiş, kişinin iş dışında kendini geliştirmeye yönelik yaptığı aktiviteler ile kurumun sunduğu kişisel gelişim olanaklarına ilişkin örtüşme, değer uyumunu ya da uyumsuzluğunu işevuruk olarak tanımlamak için tercih edilmiştir. İkinci olarak ise Leiter ve Maslach'ın (2005) modeli ve Rich ve arkadaşlarının (2010) çalışması, çeşitli iș özelliklerine dair uyumun tükenmişliği genel değer uyumu aracılığı ile etkileyeceğini öne sürmüştür. Burada tanımlanan genel değer uyumu, kişinin kurumla olan değer uyumunu evrensel olarak tasvir etmektedir (örnek değer uyumsuzluğu maddesi: "Burada çalışmak beni değerlerimden ödün vermeye zorlar"). Bu çalışmada ise kişinin belirli bir iş kaynağına (kurumun sunduğu kişisel gelişim olanakları) ilişkin değer uyumunun etkisi sinanacaktır.

Kurumun sunduğu kişisel gelişim olanakları, çalışanların kurumlarının kendilerini geliştirmelerine imkân tanıyan aktiviteler ve firsatlar sunduğuna ilişkin algısı olarak tanımlanmaktadır (Kraimer, Seibert, Wayne, Liden ve Bravo, 2011). Kurumlar hem çalışanlarının yetkinliklerini hem de kurumun cezbedici yönünü artırmak için onlara çeşitli kişisel ve mesleki gelişim olanakları sunmaktadır. Bu olanaklara örnek olarak, kurum içi kişisel gelişim seminerleri, kariyer eğitimleri, çalıştaylar ve kurumların organize ettiği yol göstericilik programlar1 gibi resmi kurumsal uygulamalar ve kaliteli lider-üye etkileşimleri gibi resmi olmayan uygulamalar verilebilir. Kurumun sunduğu kişisel gelişim olanakları, kuruma bağlılık (Bartlett, 2001), iş motivasyonu ve örgütsel vatandaşlık davranışı (Dysvik ve Kuvaas, 2008) gibi kavramlar ile pozitif, işten ayrılma niyetiyle ise negatif yönde (Ito ve Brotheridge, 2005) ilişkili bulunmuştur. $\mathrm{Bu}$ sebeplerle önemli bir iş kaynağı olarak karşımıza çıkmaktadır.

Bu çalışmada çalışanların kişisel gelişim olanaklarına verdikleri değer ise iş dışı zamanlarında kendilerini geliştirmeye yönelik yaptıkları aktiviteler aracılığıyla ölçülmüştür. Bu amaçla İyileşme Deneyimi Ölçeği'nin uzmanlaşma boyutu kullanılmıştır. Bu boyut, dil dersleri almak, yeni bir hobi edinmek gibi kişilerin kendilerini geliştirmek ve yeni şeyler öğrenmek amacıyla sergiledikleri iş dışı aktiviteleri kapsamaktadır (Sonnentag ve Fritz, 2007). Bu kavramı kişisel gelişime verilen değer ile ilişkilendirmemizin sebebi ise iki kavram arasındaki benzerlik ve uzmanlaşma aktivitelerinin tamamlanmaS1 için öz denetimin gerekliliğidir (Sonnentag ve Fritz, 2007). Çalışanların özellikle mesaileri bittiğinde evlerinde dinlenmek yerine bu aktiviteleri tercih etmeleri kişisel gelişimlerine verdikleri değerin göstergesi olabilir. Nitekim değerlerle öz denetim ilişkisini araştıran kuram ve araştırmalar, öz denetimin değerler tarafindan güdülendiğine işaret etmektedir (Bandura, 1991; Vohs ve Baumeister, 2004). Kişisel gelişime verilen öneme dair alınacak doğrudan bildirimlerin sosyal beğenirlik yanl1lığına sebep olacağı da göz önüne alınarak bu kavram uzmanlaşma aktiviteleri aracılığı ile ölçülmüştür.

Uzmanlaşma aktiviteleri ile kurumun sunduğu kişisel gelişim olanakları değerlerinin farkı biçiminde oluşturulan değer uyumu kavramında değer uyumu durumu, çalışanın kişisel gelişime önem verdiği ve kurumun kişisel gelişimi destekleyici kaynakları sunduğu ya da çalışanın kişisel gelişime değer vermediği ve kurumun da kişisel gelişim olanakları sunmadığı durumları içermektedir. Değer uyumsuzluğu durumu ile de çal1şanın kişisel gelişime önem vermemesi ancak kurumun kişisel gelişim olanakları sunması ya da kişinin gelişim olanaklarına önem vermesi ancak kurumun bu olanakları sağlamaması durumları tanımlanmaktadır. Buna benzer bir değer uyumu kavramsallaştırması Brandstätter, Job ve Schulze (2016) tarafından da uygulanmıştır. Araştırmada yazarlar, güç ve ilişsi güdüleri ile bu güdüleri karşılayacak iş kaynaklarının uyumunun tükenmişlik ve fiziksel şikâyetlerle ilişkisini incelemişlerdir. Sonuçta ise ilişki güdüsü uyumsuzluğunun tükenmişlikle, güç güdüsü uyumsuzluğunun ise fiziksel şikâyetlerle eğrisel ilişki gösterdiği tepki yüzey analizleri ile saptanmıştır. $\mathrm{Bu}$ kavramsallaştırmadan hareketle araştırma, çalışanların özel yaşamlarında kendilerini geliştirmeye yönelik yaptıkları şeyler ile kurumlarında kendilerini geliştirmeye yönelik sunulan olanak durumunun uyumlu olduğu durumda, olmadığı durumlara kıyasla daha yüksek işe adanmışlık deneyimleyeceklerini öngörmüştür. Başka bir deyişle değer uyumu ile işe adanmışlık arasında eğrinin iki ucunun uyumsuzluk durumlarını, ortasının ise uyum durumunu yansıttığ 1 ters dönmüş $U$ biçiminde eğrisel bir ilişki olacağı düşünülmüştür.

Yukarıda sunulan Tükenmişliğin ve Adanmışlığın Aracılık Modeli ve değer uyumunu inceleyen araştırma sonuçlarına ek olarak Vroom'un Beklenti Kuramı (1964) da bu düşünceyi destekler niteliktedir. Beklenti Kuramı'na göre kurumlar çalışanlar için birtakım kaynaklar ya da ödüller sağlayabilirler ancak çalışanlar bu kaynakları değerli bulmazlar ise sunulan olanaklar bir işe yaramayacaktır. Kraimer ve arkadaşlarının (2011) çalışması da bir açıdan buna işaret etmektedir. Kişisel gelişim olanaklarının olumlu çıktılara etkisi yalnızca çalışanlar bu uygulamaların kurumdaki kariyerlerinde 
fayda sağlayacağını düşündüklerinde gerçekleşmiştir. $\mathrm{Bu}$ durum kurumun sunduğu gelişim olanakları ile işe adanmışlık ilişkisine uyarlanırsa olanakların işe adanmışlığa etkisinin, çalışanların bu olanaklara atfettikleri değer ölçüsünde gerçekleşebileceği ileri sürülebilir. İş talepleri ve kaynakları ile işe adanmışlık arasındaki ilişkiyi 11 ülkede sınayan bir araştırma, iş kaynaklarından yönetici desteği ve kariyer kimliğinin işe adanmışlık ile pozitif bir ilişki gösterdiğini, çalışanlara sağlanan kariyer gelişim olanaklarının işe adanmışlık ile bir ilişki göstermediğini ortaya koymuştur (Lee ve Eissenstat, 2018). $\mathrm{Bu}$ çalışma da aslında iş kaynaklarından gelişim olanakları ve işe adanmışlık arasındaki doğrusal ilişkiyi sorgulamamızı destekler niteliktedir. Bu bağlamda kişinin iş dışında kendini geliştirmeye yönelik yaptığ 1 aktiviteler ile kurumun sunduğu kișisel gelişim olanaklarına ilișkin örtüşme, yani eğrisel bir ilişki olarak ifade edilen değer uyumunu ya da uyumsuzluğunun işe adanmışlık ile ilişkisine odaklanmak son derece mantıklı görünmektedir. Bu bilgiler doğrultusunda:

Hipotez 1: Kurumun sunduğu gelișim olanaklarına ilişkin kişi-kurum değer uyumu ile işe adanmışlık arasında ters dönmüş $\mathrm{U}$ biçiminde eğrisel bir ilişki mevcuttur. $\mathrm{Bu}$ olanaklar, çalışanlar onları değerli gördügü ölçüde işe adanmışlı̆̆ pozitif yönde etkileyecektir.

\section{Kurumda Çalışma Süresinin Düzenleyici Rolü}

Tükenmişliğin ve Adanmışlığın Aracılık Modeli'nde de belirtildiği üzere çalışanlar kültürel arka planları, aile yaşantıları gibi faktörlerce şekillenmiş farklı değerlere sahiplerdir. Benzer şekilde kurumlar da yönetimleri ve çalışanları tarafından şekillendirilen birtakım değerlere sahiplerdir. İş arama sürecinden itibaren çalışan adayları, sahip oldukları değerlerin çalışacakları kurumlarla uyumlu olup olmadığını dikkate almaktadırlar (Resick, Baltes ve Shantz, 2007). Kurumlar da çalışan cezbetme ve işe alım süreçlerinde kurum değerleriyle uyumlu çalişanlar tercih etme eğilimindedirler (Cable ve Judge, 1997). Kurumlar çalışanları işe aldıktan sonra birtakım uygulamalar ile yeni çalışanlarına kurum değerlerini aşılamaya çalışmakta ve bu uygulamalardan fayda sağlamaktadırlar. Örneğin, Kim, Cable ve Kim (2005) kurumun uyguladığ1 uyum sağlama taktiklerinin çal1şan kişi-kurum uyumu bildirimleri ile ilişkili olduğunu, bu ilişkinin çalışana bağlı proaktif davranış ile daha da kuvvetlendiğini saptamışlardır. Değer uyumu sağlanamadığında ise çalışanların işi bırakma eğilimi daha fazla olmaktadır (Cable ve Parsons, 2001). Bu çalışmalar, çalışanın işe girme sürecinden itibaren başlayan kişi ile kurum arasındaki değerlerin birbirine benzemesine yönelik bir sürecin olduğuna işaret etmektedir. Çekim Seçim Yıpranma Modeli (Schneider, 1987) de bu süreci tanımlamaktadır. Modele göre çalışan adayları kişilikleri ve değerleri ile uyumlu kurumları çekici bulmakta ve bu kurumları tercih etme eğilimi ve davranışı göstermektedirler. Benzer şekilde kurumlar da kurum değerleri ile uyumlu çalışan adaylarını seçme eğilimindedirler. Modelin son aşaması ise kurum hedefleri ve değerleri ile uyum sağlayamayan çalışanların kurumlarından ayrıldıklarını ve böylece kurumların daha homojen yapıda kişilik ve değer örüntüsü gösteren kişilerden oluştuklarını iddia etmektedir. Modelden hareketle bu çalışmada da değer uyumu ile işe adanmışlık ilişkisinin kurumda çalışma süresi yüksek katılımcılar için daha benzer olacağ1 öngörülmektedir. Çalışanların kurumlarında çalıştıkları süre arttıkça çeşitli kurumsal uygulamalar ya da çalışma arkadaşlarının etkisi ile kurumun sağladığı gelişim olanaklarına dair değerleri kurumları ile birbirine benzeyecektir. Sonuçta ise kurumda çalışma süresi yüksek çalışanlar, kurumda çalışma süresi düşük çalışanlara kıyasla birbirine daha benzer değer uyumu gösterecek, dolayısıyla bu çalışanlar arasında gözlemlenen değer uyumu-işe adanmışlık ilişkisi daha homojen olacaktır.

Çekim Seçim Yıpranma Modeli çalışanların iş arama, kurumların ise çalışan cezbetme sürecinden başlayarak değer uyumunu gözettiklerini dile getirse de çeşitli faktörler işe alınan çalışanlarla kurumlar arasında değer uyumsuzluğu yaşanmasına sebep olabilir. Örneğin çal1şanlar daha iyi iş teklifleri elde edebilmek için izlenim yönetimi stratejileri kullanabilmektedirler (Leary ve Kowalski, 1990). Kurumlar ise farklılık politikaları gibi sebeplerle düşük değer uyumu gösteren çalışan adaylarını işe alabilmektedirler (Schneider ve ark., 1995). Değer uyumsuzluğu işe adanmışlık ile negatif yönde ilişkilidir (Rich ve ark., 2010). Bunun yanı sıra Çekim Seçim Yıpranma Modeli değer uyumsuzluğu yaşayan çalışanların işi bırakma eğilimleri olacağını öne sürmektedir (Schneider, 1987). Öte yandan çalışanlar iş ortamlarındaki etkileşimlerde farklı pek çok deneyime ve etkiye maruz kalmakta ve kendileri de yeni iş ortamlarına uyum sağlayabilmek için çeşitli uyum stratejileri benimsemektedirler. Bu deneyim ve davranışlardan bazıları değer uyumsuzluğunun işe adanmışlık üzerindeki negatif etkisini telafi edebilir. Nitekim değer uyumsuzluğunun çeşitli çalışan çıktıları üzerindeki negatif etkisini inceleyen çalişmalar birtakım kurumsal uygulamalar ve çalışana ilişkin süreçlerin telafi edici bir işlev gösterebileceğini bulmuşlardır. Örneğin, Erdogan, Kraimer ve Liden (2004) lider üye etkileşimi ve algılanan örgütsel desteğin değer uyumsuzluğunun iş ve kariyer doyumu üzerindeki negatif etkisini hafiflettiğini göstermişlerdir. Vogel, Rodell ve Lynch (2016) ise iş şekillendirmenin değer uyumsuzluğu ile çalışan adanmışlığı ve iş performansı arasındaki ilişkide negatif etkiyi azaltarak bir tampon görevi gördügünü bulmuşlardır. Çalışanların bu olumlu uygulamaları deneyimlemeleri ya da kendilerine uygun uyum biçimini 
belirleyebilmeleri için gerekli faktörlerden birisi doğal olarak kurumda çalışma süresidir (Reio ve Sutton, 2006; Saks ve Ashforth, 1997). Bu bilgiler ışığında aşağıdaki hipotez oluşturulmuştur.

Hipotez 2: Kurumdaki çalışma süresi, kurumun sunduğu gelişim olanakları değer uyumu ile işe adanmışlık eğrisel ilişkisi arasında düzenleyici rol oynayacaktır. Kuruma yeni katılmış çalışanlar için değer uyumsuzluğu ile işe adanmışlık arasındaki ilişki daha fazla olacak; diğer bir deyişle bu çalışanlar için eğrinin eğim düzeyi daha fazla olacaktır.

\section{Örneklem}

\section{Yöntem}

Araştırmaya İzmir'de, hizmet, inşaat ve finans gibi farklı sektörlerde çalışmakta olan 204 beyaz yaka çalışan katılmıştır. Katılımcıların \%50'si kadın, \%50'si erkektir. Katılımcıların yaş ortalaması 36.1 yıldır. $(S=8.7)$. Katılımcıların \%12'si lise, \%16's1 ön lisans, \%60'1 lisans mezunudur ve \%12'si yüksek lisans ve doktora derecesine sahiptir. Katılımcıların şu anki işlerinde çalışma sürelerinin ortalaması 14.1 yıl $(S=9.7)$ ve kurumda çalışma sürelerinin ortalaması ise 6.9 yıldır $(S=6.4)$.

\section{Veri Toplama Araçlart}

İşe Adanmışlık Ölçeği. Schaufeli ve arkadaşları (2002) tarafından geliştirilen İşe Adanmışlık Ölçeği'nin Türkçeye uyarlama, geçerlik ve güvenirlik çalışması Eryılmaz ve Doğan (2012) tarafından yapılmıştır. Ölçek 17 maddeden ve dinçlik, işe bağlanma ve işe yoğunlaşma olmak üzere üç boyuttan oluşmaktadır. Ölçeğin yanıt bölümü 5'li Likert tipi olup, yanıtlar "1 = Hiç uygun değil, 5 = Tamamen uygun" şeklinde puanlanmaktadır. Yüksek puan daha fazla işe adanmışlığı göstermektedir. Ölçeğin "dinçlik" boyutuna "İşimde kendimi enerji dolu hissederim”, "işe bağlanma” boyutuna "İşime karş1 istekli ve hevesliyim" ve "işe yoğunlaşma" boyutuna "Çalışırken zaman su gibi akıp gider" ifadeleri örnek gösterilebilir. Türkçeye uyarlama çalışmasında rapor edilen Cronbach Alfa güvenirlik katsayısı tüm ölçek için 0.94 'tür. Dinçlik, işe bağlanma ve işe yoğunlaşma boyutları için Cronbach Alfa katsayıları sırasıyla 0.87, 0.87 ve 0.84 'tür.

İyileşme/İyileştirme Deneyimi Ölçeği. Kişilerin iş dişındaki toparlanma deneyimlerini ölçen İyileşme Deneyimi Ölçeği psikolojik kopma, rahatlama, uzmanlaşma ve kontrol olmak üzere 4 alt boyuta ve toplamda 16 maddeye sahiptir (Sonnentag ve Fritz 2007). Ölçeğin Türkçeye uyarlama çalışması Koçak ve arkadaşları (2016) tarafından yapılmış, Koçak (2017) tarafından tekrar gözden geçirilmiştir. Ölçeğin yanıt bölümü 5'li Likert tiptedir ( 1 = Hiç Katılmıyorum, 5 = Tamamen Katılıyorum). Çalışma kapsamında ölçeğin dört maddeden oluşan uzmanlaşma alt boyutu kullanılmıştır. "Kendimi geliştirmek için entelektüel konular araştırıyorum”, bu boyutun örnek maddesidir. Bu boyutun Cronbach Alfa güvenirlik katsayısı 0.86 'dır.

İş Kaynakları Ölçeği. Katılımcıların çalıştıkları işlerin sağladığı kaynakları (özellikleri) belirlemek için İş Kaynakları ölçeği kullanılmıştır. Bu ölçek özerklik, sosyal destek, yönetici koçluğu, geribildirim, işin önemi ve kişisel gelişim olanakları alt boyutlarına sahiptir. Bu araştırmada sadece "kişisel gelişim olanakları" alt boyutu kullanılmıştır. Kişisel gelişim olanakları alt boyutunun orijinal maddeleri Bakker, Demerouti, Taris, Schaufeli ve Schreurs (2003) tarafından geliştirilmiştir. Üç maddeden oluşan alt boyutun Türkçeye uyarlaması ise Koçak (2013) tarafından yapılmıştır. Kullanılan kişisel gelişim olanakları alt boyutunun cevap bölümü 6'l1 Likert tipi (1 = Hiç katılmıyorum, 6 = Tamamen katılıyorum) olup, rapor edilen Cronbach Alfa güvenilirlik katsayısı 0.88'dir. "İşimde güçlü olduğum yönlerimi geliştirebileceğim imkânlar var”, bu alt ölçekten örnek bir maddedir.

Kişisel Bilgi Formu. Katılımcılardan yukarıda belirtilen ölçekleri yanıtlamanın yanı sıra cinsiyet, yaş, eğitim durumu, çalıştıkları pozisyon, kurumda çalışma süreleri gibi kişisel bilgileri içeren bilgi formunu da doldurmaları istenmiştir.

\section{İşlem}

Çalışma için gerekli etik izin alınmış ve örneklemi oluşturmak amaciyla kişilere yüz yüze ya da telefon aracılığıyla ulaşılmıştır. Araştırmaya katılmayı kabul eden çalışanlarla internet üzerinden bir bağlantı paylaşılmış ve bu bağlantı üzerinden anketi doldurmaları istenmiştir. Katılımcılar tarafindan doldurulan anketler isimleri gizli kalacak şekilde araştırmacılara ulaşmıştır. Ayrıca katılımcılardan anketi doldurmadan önce haklarını ve araştırmaya tamamen gönüllü olarak katıldıklarını belirten "Bilgilendirilmiş Onam Formunu" imzalamaları istenmiştir.

\section{Bulgular}

Hipotezlerin testinden önce çalıșma ölçeklerinin ayr1 yapıları ölçüp ölçmediğini test etmek için üç faktörlü doğrulayıcı faktör analizi uygulanmıştır. Analiz sonuçları İşe Adanmışlık Ölçeği'ndeki Madde 15'in ("İşimde kendimi zihinsel olarak oldukça dinç hissederim”) çıkarılması ve yine bu ölçekte maddeler arasındaki dört hata kovaryansının serbest bırakılmasıyla test edilen modelin veriye kabul edilebilir düzeyde uyum sağlad1ğ1nı göstermiştir, $\chi^{2}(222, N=204)=411.17, p<.001$, RMSEA $=.07, \mathrm{TLI}=.90, \mathrm{CFI}=.91$. Modelde tüm ölçek maddelerinin faktörlerinden .30 ve üzerinde yük aldığ 1 gözlemlenmiştir. Ortak yöntem varyansının söz konusu olup olmadığının testi için tüm maddelerin tek bir fak- 
Tablo 1. Değişkenlerin Ortalama Standart Sapma ve Korelasyon Değerleri

\begin{tabular}{|c|c|c|c|c|c|c|c|c|}
\hline Ölçek & Ort. & $S$ & 1 & 2 & 3 & 4 & 5 & 6 \\
\hline 1. Yaş & 36.11 & 8.70 & - & & & & & \\
\hline 2. Cinsiyet ${ }^{\mathrm{a}}$ & - & - & .08 & - & & & & \\
\hline 3. Kurumdaki çalışma süresi & 6.92 & 6.46 & $.55^{* *}$ & -.11 & - & & & \\
\hline 4. İşe adanmışlık & 3.72 & 0.73 & .03 & .09 & -.06 & $(.93)$ & & \\
\hline 5. Kişisel gelişim olanakları & 4.89 & 1.04 & .09 & $.23 * *$ & -.08 & $.64 * *$ & $(.88)$ & \\
\hline 6. Uzmanlaşma aktiviteleri & 3.71 & 0.81 & .13 & $.19^{*}$ & $-.15^{*}$ & $.38^{* *}$ & $.42 * *$ & $(.71)$ \\
\hline 7. UA - KG fark değiş̧keni & -0.43 & 1.09 & .03 & -.05 & -.07 & $-.28 * *$ & $-.59 * *$ & $.49 * *$ \\
\hline
\end{tabular}

Not 1. $N=$ 204. KG: Kișisel gelișim olanakları; UA: Uzmanlaşma aktiviteleri. ${ }^{a}$ Kadın $=1$ Erkek = 2. Köșegenlerde parantez içinde verilen değerler ölçeklerin Cronbach Alfa güvenirlik değerleridir.

Not 2. ${ }^{*} p<.05,{ }^{* *} p<.01$.

törden yük aldığ 1 yapı da sınanmış ve bu yapının veriye kötü uyum gösterdiği tespit edilmiştir, $\chi^{2}(229, N=204)$ $=739.47, p<.001, \mathrm{RMSEA}=.11, \mathrm{TLI}=.74, \mathrm{CFI}=.76$. $\mathrm{Bu}$ sonuçlar ölçüm araçlarının ayrışık yapıda olduğunu göstermektedir.

Değişkenlerin ortalama ve standart sapma değerleri ile değişkenler arasındaki korelasyonlar Tablo 1'de verilmiştir. Değerler incelendiğinde işe adanmışlık ve kurumun sunduğu kişisel gelişim olanakları $(r=.64, p<$ $.001)$ ile işe adanmışlik ve uzmanlaşma deneyimleri $(r=$ $.38, p<.001)$ arasında pozitif yönde ve anlamlı korelasyon olduğu görülmüştür. Buna ek olarak kişisel gelişim olanakları bildirimleri ile uzmanlaşma aktiviteleri arasındaki korelasyon da beklenti dışı olarak anlamlıdır ( $r$ $=.42, p<.001)$. Bu sonuç, iş dış1 yaşantılarında kendini geliştirmeye yönelik aktivitelerle daha fazla meşgul olan kişilerin kurumun sunduğu kişisel gelişim olanaklarına da daha duyarlı oldukları veya bu olanakları sunduğu bilinen kurumlarla çalışmayı tercih ettikleri biçiminde yorumlanabilir. Son olarak, kadın çalışanların kurumun sunduğu kişisel gelişim olanakları $(r=.23, p=.001)$ ile uzmanlaşma aktivitelerini daha fazla $(r=.19, p=.006)$ bildirdiği görülmüştür.

Hipotez 1'in testi için kullanılacak polinom regresyon analizleri ile tepki yüzey analizinin uç değere sahip verilerden özellikle etkilendikleri raporlanmıștır (Belsley, Kuh ve Welsch, 1980). Bu nedenle regresyon üzerinde kuvvetli etkileri olan uç değerleri belirlemek için kullanılan Cook uzaklığı ile kaldıraç noktası değerleri Denklem 1 temel alınarak incelenmiştir. Cook uzaklığ1 ve kaldıraç noktası ortalama değerlerinin üç katının üzerinde değere sahip katılımcılar ile Cook uzaklığ1 - kald1raç noktası grafiğinin incelenmesiyle saptanan uç değere sahip toplam 10 katılımcı, sonraki analizlere dâhil edilmemiştir (Edwards ve Cable, 2009).
Hipotez 1 kurumun sunduğu kişisel gelişim olanaklarına ilişkin değer uyumu ile işe adanmışlık arasında ters dönmüş $U$ biçiminde eğrisel bir ilişkinin olacağını öne sürmüştür. Hipotez testi için ilk olarak uyum yazınında yaygın olarak kullanılan yöntem olan fark değeri (Uzmanlaşma Aktiviteleri - Kişisel Gelişim Olanakları) hesaplanmış ve polinom regresyon analizi uygulanmıştır (Kristof-Brown, Zimmerman ve Johnson, 2005; Verquer, Beehr ve Wagner, 2003). Fark değeri hesaplanmadan önce Kişisel Gelişim Olanakları Ölçeği ile Uzmanlaşma Aktiviteleri Ölçeğinin derecelendirme noktalarını aynı uzaklığa getirmek için 5'li Likert yapıya sahip Uzmanlaşma Aktiviteleri değişkeni 6/5 katsayısı ile çarpılmıştır. Bu sayede iki ölçeğin uzaklıklarının eşit olması sağlanmıştır. Regresyon analizi aşamalı olarak gerçekleştirilmiştir. İlk aşamada yaş ve cinsiyet kontrol değişkenleri olarak girilmiş, ikinci aşamada fark değişkeni eklenmiş, üçüncü aşamada ise ikinci derece (karesi alınmış) fark değişkeni modele eklenmiştir. İkinci derece değişkenin modele anlamlı düzeyde katkı sağlaması eğrisel ilişkinin anlamlı olduğunu göstermektedir.

Analiz sonuçları yaş $(\beta=-.02, p=.81)$ ve cinsiyetin $(\beta=.11, p=.14)$ işe adanmışlık ile anlamlı düzeyde ilişkili olmadığını göstermiştir. Uyum değişkeninin doğrudan etkisi ise anlamlıdır $(\beta=-.18, p<.011)$. Bu sonuç, değer uyumsuzluğunu çalışanın gelişim olanaklarına önem vermesi ancak kurumun bu olanakları sağlamamas1 biçiminde deneyimleyen çalışanların, uyumsuzluğu kurumun bu olanakları sağlaması ancak çalışanın düşük düzeyde önem vermesi biçiminde deneyimleyenlere k1yasla daha düşük işe adanmışlık bildirdiklerini göstermektedir. Modele eklenen ikinci derece değişkenin etkisi de anlamlıdır $(\beta=-.32, p<.001)$. Bu sonuç, hipotez edilen eğrisel ilişkinin anlamlı olduğunu; diğer bir deyişle çalışanların iş dışı yaşantılarında kendilerini geliştirme- 
ye yönelik yaptıkları aktiviteler ile kurumlarındaki bu değerlerini gerçekleştirmeye yönelik sağlanan olanakların uyumlu olduğu durumda daha yüksek işe adanmışlık raporladıklarına işaret etmektedir (bkz. Şekil 2).

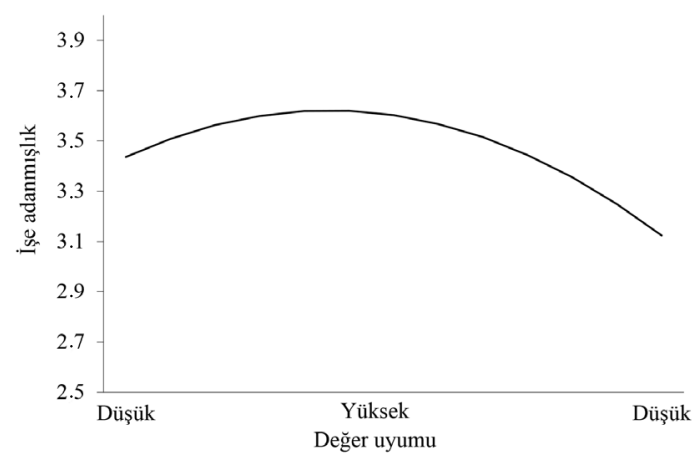

Not. Regresyon eğrisinin sol ucu yüksek düzeyde kurumun sunduğu gelişim olanakları ile düşük düzeyde kişisel gelişime verilen önemden kaynaklı değer uyumsuzluğunu, sağ ucu ise düşük düzeyde kurumun sunduğu gelişim olanakları ile yüksek düzeyde kişisel gelişime verilen önemden kaynaklı değer uyumsuzluğunu göstermektedir.

Şekil 2. Değer Uyumu ile İşe Adanmışlık Arasındaki Eğrisel İlişki Grafiği

Uyum indeksini fark değişkeni olarak kullanmanın çeşitli dezavantajları olduğu belirtilmektedir. $\mathrm{Bu}$ dezavantajlar fark değişkeni oluşturmak için kullanılan değişkenlerin bağımlı değişken üzerindeki bireysel etkilerine ilişkin bilginin kaybolması, yine bu yöntem sonucu oluşan kavram muğlaklığı ve değişkenlerin fark değişkeni olarak dönüştürüldüklerinde açıkladıkları toplam varyansın kaçınılmaz olarak azalması olarak sıralanabilir (Edwards, 1994a, 2001; Kristof, 1996). Bunlara ek olarak bu çalışmada fark değișkeni oluşturmak için kullanılan değişkenler arasında orta büyüklükte $(r=.42$, $p<.001)$ korelasyon olduğu gözlenmiştir. Edwards ve Parry (1993) uyum ya da uyumsuzluğu test edebilmek için alternatif bir yöntem önermişlerdir. Tepki yüzey analizi adı verilen bu yöntemde, uyumunun ya da uyumsuzluğunun etkisi sınanmak istenen değişkenlerin ikinci derece terimlerinin yer aldığı bir denklemden oluşturulan üç boyutlu yüzey grafiği incelenmektedir:

Denklem 1: $\mathrm{IA}=b_{0}+b_{1} \mathrm{KG}+b_{2} \mathrm{UA}+b_{3} \mathrm{KG}^{2}+b_{4} \mathrm{~K}-$ $\mathrm{G} \times \mathrm{UA}+b_{5} \mathrm{UA}^{2}+e$

Denklem 1'de İA işe adanmışlığı, KG kişisel gelişim olanaklarını ve UA uzmanlaşma aktivitelerini temsil etmektedir. Denkleme ikinci derece terimler $\left(\mathrm{KG}^{2}\right.$, $\mathrm{KG} \times \mathrm{UA}, \mathrm{UA}^{2}$ ) değer uyumu etkisinin olup olmadığını sınamak için eklenmiştir (Edwards, 2002).
Ters dönmüş U biçiminde uyumu temsil eden ideal yüzey grafiği Şekil 3 'te verilmiştir. Edwards ve Parry (1993) yüzey grafiğinde uyum ya da uyumsuzluk etkisinin olup olmadığının tespiti için çeşitli ölçütlerden söz etmişlerdir. İlk olarak eklenen ikinci derece terimlerden en az birisinin modele anlamlı düzeyde katkı sağlaması gerekmektedir. İkinci derece etkiler anlamlı değilse ancak doğrusal etkilerden söz edilebilir. İkinci olarak yüzeyin uyumsuzluk doğrusu boyunca aşağı yönlü eğimli olması gerekmektedir. Diğer bir deyişle $b_{3}-b_{4}+b_{5}$ toplamının negatif yönde olması gerekmektedir. Üçüncü olarak yüzeyin doruk yaptığı kısmın uyum doğrusu boyunca uzanması gerekir. Bu durum bağımlı ölçümün uyumluluk olduğunda daha yüksek değerler aldığının göstergesidir. Bu ölçütün testi, yüzeyin birinci asal eksenin 1 eğim değeri ve 0 kesme noktası değerine sahip olup olmadığı ile test edilir. Dördüncü ölçüt ise yüzeyin, uyumu test edilen değişkenlerin tüm değerleri boyunca düz bir biçimde ilerleyip ilerlemediği, diğer bir deyişle uyumu test edilen değişkenlerin düşük ve yüksek düzeylerinde aynı sonucu verip vermediğinin testi ile ilişkilidir. $\mathrm{Bu}$ ölçüt ise $b_{1}+b_{2}$ ve $b_{3}+b_{4}+b_{5}$ toplamlarının 0 'dan anlamlı olarak farklı olmaması ile karşılanır.

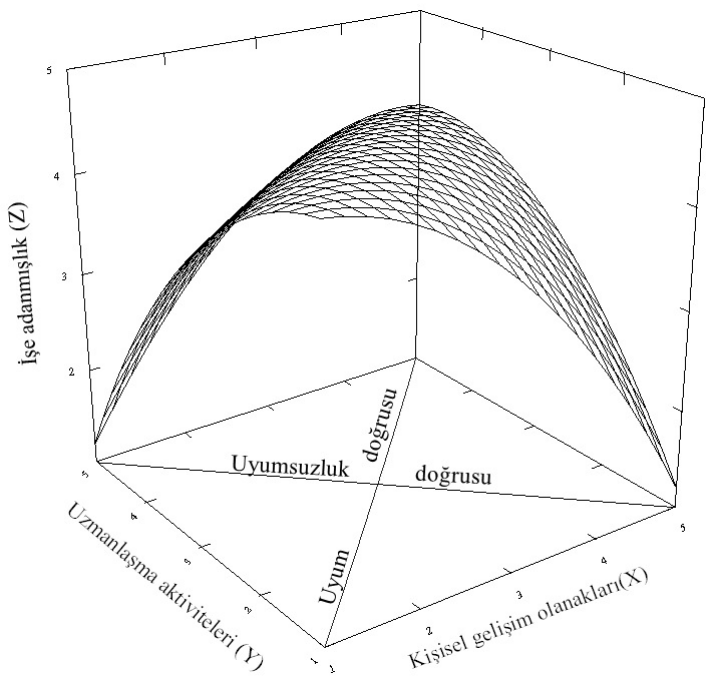

Şekil 3. Uyum Durumunu Temsil Eden Tepki Yüzey Grafiği Örneği

Denklem 1 çoklu regresyon ile analiz edilmiştir. Analizden önce Edwards'ın (1994b) önerisi doğrultusunda kişisel gelişim olanakları ve uzmanlaşma aktiviteleri değişkenleri ölçek orta noktasında merkezlenmiştir. Regresyon sonuçları Tablo 2'de verilmiştir. Sonuçlar incelendiğinde denklemdeki ikinci derece değişkenlerden $\mathrm{KG} \times \mathrm{UA}$ 'nın etkisinin anlamlı olduğu görülmektedir. $\mathrm{Bu}$ 
Tablo 2. Tepki Yüzey Analizi Regresyon Denkleminin Katsayıları

\begin{tabular}{lcc}
\hline Değişkenler & $\beta$ & $p$ \\
\hline Kişisisel gelişim olanakları (KG) & .48 & .004 \\
Uzmanlaşma aktiviteleri (UA) & .641 \\
$($ Kişisel gelişim olanakları) & \\
KG×UA & -.08 & .211 \\
$($ Uzmanlaşma aktiviteleri) &. .27 & .011 \\
\hline
\end{tabular}

Not. $N=194$.

sonuçlar, kişisel gelişim olanakları ile uzmanlaşma aktiviteleri uyumunun etkisinin olabileceğine dair ilk ölçütü sağlamaktadır. İkinci ölçütün testi SPSS programında GLM LMATRIX komutu kullanılarak gerçekleştirilmiştir. Analiz sonucu $b_{3}-b_{4}+b_{5}$ toplamının negatif yönde olduğu ve bu etkinin 0'dan anlamlı düzeyde farklı olduğu görülmüş $(p=.042)$, dolayısıyla bu ölçüt de karş1lanmıştır. Üçüncü ölçütün testi, regresyon katsayılarının doğrusal olmayan kombinasyonlarını içerdiği için bootstrap yöntemi kullanılarak gerçekleştirilmiştir (Edwards ve Cable, 2009; Efron ve Tibshirani, 1993). Yöntemde Denklem 1'den hareketle oluşturulan bootstrap analizi sonucu elde edilen güven aralığı değerlerinin eğim için 1'i, kesme noktası için 0'1 içermesi gerekmektedir. On bin bootstrap örneklemi kullanılarak gerçekleştirilen analiz sonucu elde edilen yanlılığı giderilmiş güven aralığ1 değerlerinde eğim değerinin \%95 güven aralığında 1'i (\%95 GA[0.58 - 2.60]), kesme noktasının değerinin ise \%96 güven aralığında 0’1 (\%96 GA[-12.77 - 0.06]) içerdiği görülmüştür. Bu sonuçlar üçüncü ölçüte büyük ölçüde destek sunmaktadır. Dördüncü ölçütün sınanması ise birinci ölçütte olduğu gibi GLM LMATRIX ile yapılmıştır. Analiz sonuçları hem $\mathrm{b}_{1}+\mathrm{b}_{2}$ toplamının $(p=$ $.058)$, hem de $b_{3}+b_{4}+b_{5}$ toplamının $(p=.158) 0$ 'dan anlamlı düzeyde farklı olmadığını göstermiş ve bu ölçütü karşılamıştır. Tepki yüzey analizine ilişkin yüzey grafiği Şekil 4'te verilmiştir. Uyum etkisinin varlığı, hem fark değerine uygulanan polinom regresyon hem de tepki yüzey analizi ile desteklenmiştir. Bu sonuçlar kişilerin iş dışı yaşantılarında sergiledikleri uzmanlaşma deneyimleri ile kurumun kendilerine sunduğu kişisel gelişim olanaklarının uyumlu olduğu durumda uyumsuz olduğu durumlara kıyasla daha yüksek işe adanmışlık raporladıklarını göstermektedir. Sonuçlardan hareketle Hipotez 1 desteklenmiştir.

Hipotez 2, uzmanlaşma aktiviteleri kişisel gelişim olanakları uyumunun görece yeni çalışanların işe adanmışlıkları üzerinde daha etkili olacağını, diğer bir deyişle uyum ile işe adanmışlık arasındaki ilişkinin yeni çalışanlar için daha eğrisel olacağını öne sürmüştür. Hipotez testi, beş basamaklı regresyon modeli ile yapılmış- tır. İlk basamakta kontrol değişkenleri sınanmış, ikinci basamakta uyum değişkeni ile kurumdaki çalışma süresi modele eklenmiştir. Üçüncü basamakta karesi alınmış fark değişkeni, dördüncü basamakta kurumdaki çalışma süresi ile birinci derece fark değişkeninin çarpımıyla elde edilen etkileşim değişkeni modele dâhil edilmiştir. Son basamakta ise uyum ile işe adanmışlık eğrisel ilişkisinde kurumdaki çalışma süresinin düzenleyici rol oynayıp oynamadığının testi için kurumdaki çalışma süresiyle karesi alınmış uyum değişkeninin çarpımı ile elde edilmiş etkileşim değişkeni modele dâhil edilmiştir. Birinci ve ikinci derece değişkenlerin ilişkisinden kaynaklanabilecek çoklu eş doğrusallığı engellemek amacıyla tüm birinci düzey değişkenler ortalama değerinde merkezlenmiştir.

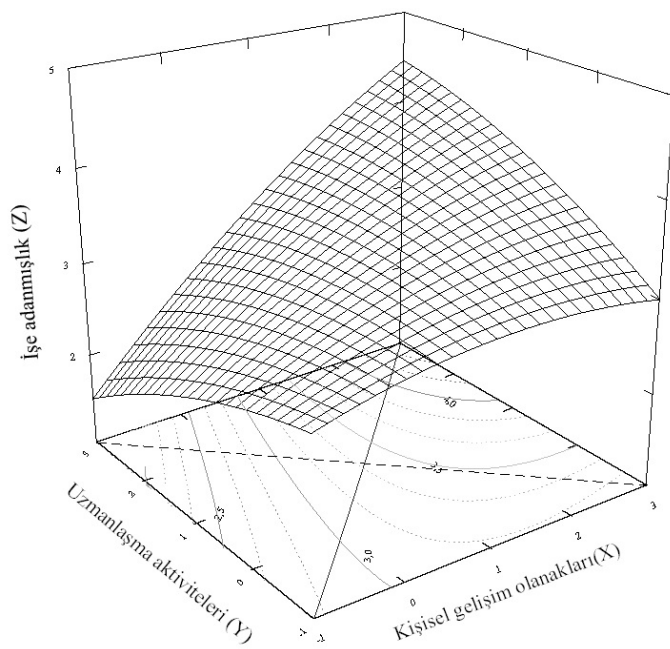

Şekil 4. Uzmanlaşma Aktiviteleri ve Kişisel Gelişim Olanaklarının İşe Adanmışlık Üzerindeki Tepki Yüzey Grafiği

Regresyon analizi sonuçları Tablo 3 'te verilmiştir. Sonuçlar incelendiğinde değer uyumunun işe adanmışlık ile negatif yönde ilişkili olduğu $(\beta=-.19, p=.008)$, kurumdaki çalışma süresinin işe adanmışlık ile ilişkisiz 
Tablo 3. Polinom Regresyon Analizi Sonuçları

\begin{tabular}{|c|c|c|c|c|c|c|c|}
\hline \multirow{2}{*}{ Değişkenler } & 1. adım & 2. adim & 3. adım & 4. adim & 5. adım & \multirow{2}{*}{$\begin{array}{c}\text { Düzeltilmiş } \\
R^{2}\end{array}$} & \multirow{2}{*}{$R^{2}$ değişim } \\
\hline & $\beta$ & $\beta$ & $\beta$ & $\beta$ & $\beta$ & & \\
\hline Yaş & .11 & & & & & & \\
\hline Cinsiyet & -.02 & & & & & $<.01$ & - \\
\hline Değer Uyumu & & $-.19 * *$ & & & & & \\
\hline Kurumdaki çalışma süresi & & -.11 & & & & .03 & .03 \\
\hline (Değer uyumu $)^{2}$ & & & $-.32 * * *$ & & & .10 & .07 \\
\hline Değer uyumu × çalışma süresi & & & & .04 & & .10 & .00 \\
\hline$(\text { Değer uyumu })^{2} \times$ çalışma süresi & & & & & $.22 *$ & .12 & .02 \\
\hline
\end{tabular}

Not $1 . N=194$.

Not $2 . * p<.05, * * p<.01, * * * p<.001$.

olduğu $(\beta=-.11, p=.183)$ görülmüştür. Değer uyumunun eğrisel ilişkisi anlamlı iken $(\beta=-.32, p<.001)$, değer uyumu ile çalışma süresi etkileşiminin işe adanmışlık ile ilişkisi anlamlı değildir $(\beta=.04, p=.652)$. Son aşamada test edilen karesi alınmış değer uyumu ile çalışma süresi etkileşiminin işe adanmışlık ile ilişkisi ise anlamlıdır $(\beta=$ $.22, p=.016)$. İlişkinin yapısını ortaya çıkarmak amacıyla kurumdaki çalışma süresinin $+1 S S$ ve $-1 S S$ değerlerindeki değer uyumu - işe adanmışlık ilişkisi incelenmiştir (bkz. Şekil 5). Grafik incelendiğinde $+1 S S$ kurumdaki çalışma süresi değerindeki değer uyumu - işe adanmışlık

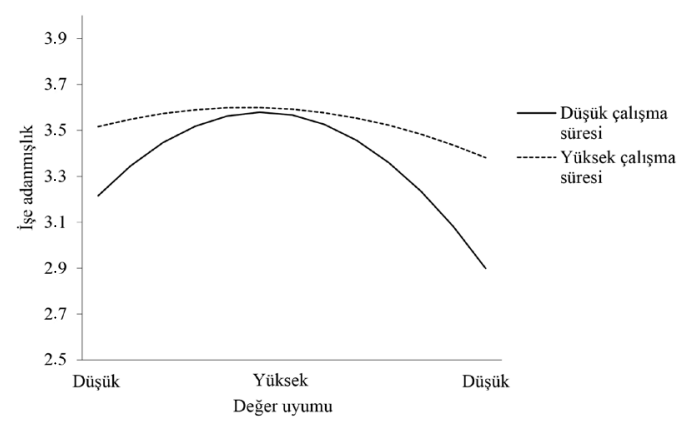

Not. Regresyon eğrisinin sol ucu yüksek düzeyde kurumun sunduğu gelişim olanakları ile düşük düzeyde kişisel gelişime verilen önemden kaynaklı değer uyumsuzluğunu, sağ ucu ise düşük düzeyde kurumun sunduğu gelişim olanakları ile yüksek düzeyde kişisel gelişime verilen önemden kaynaklı değer uyumsuzluğunu göstermektedir.

Şekil 5. Kurumdaki Çalışma Süresinin Düşük ve Yüksek Düzeylerindeki Değer Uyumu ile İşe Adanmışlık Eğrisel İlişkisi ilişkisinin, -1SS kurumda çalışma süresi değerindeki değer uyumu - işe adanmışlık ilişkisine kıyasla daha düz bir yapıda olduğu görülmektedir. Kurumdaki çalışma süreleri düşük olan çalışanlar değer uyumsuzluğu durumlarında kurumda çalışma süreleri fazla olan çalışanlara kıyasla daha düşük işe adanmışlık bildirmişlerdir. Bu sonuçlar Hipotez 2'ye destek sağlamaktadır.

\section{Tartışma}

$\mathrm{Bu}$ araştırma kurumun sunduğu kişisel gelişim olanaklarına ilişkin değer uyumu deneyimleyen çalışanların işe adanmışlık düzeylerinin daha yüksek olduğunu göstermiştir. Ayrıca değer uyumu ile işe adanmışlık arasındaki eğrisel ilişkinin kurumda çalışma süresi daha az olan çalışanlar için daha eğimli bir yapıda olduğu, diğer bir deyişle bu çalışanların işe adanmışlık deneyimlerinin uyumsuzluk durumlarından negatif yönde daha fazla etkilendiği saptanmıştır.

Çalışmanın ilk hipotezi İş Kaynakları ve Talepleri Modeli ile Tükenmişliğin ve Adanmışlığın Aracılık Modeli'nden hareketle değer uyumunun olduğu durumda olmadığı duruma kıyasla daha fazla işe adanmışlık bildirileceği yönündeydi. Modelleri destekler nitelikte değer uyumunun olduğu durumda çalışanlar daha fazla işe adanmışlık deneyimlediklerini raporlamışlardır. Bu sonuç, geçmiş araştırmalarca (Christian ve ark., 2011) çalışanlar üzerinde pozitif etkileri olduğu gösterilmiş iş kaynaklarının doğrudan etkilerinin yanı sıra çalışanların bu kaynaklara ilişkin değer uyumlarının olup olmadığının göz önüne alınması gerekliliğini de işaret etmektedir. Yine de bu çalışmanın sonuçlarının, kurumların sundu-

1 Hipotez 2'nin tepki yüzey analizi ile test edilmemesinin sebebi Kristof'un (1996) da belirttiği üzere tepki yüzey analizinin yüksek sayıda serbestlik derecesine ihtiyaç duymasıdır. Düzenleyici değişkenin tepki yüzey analizinin denklemindeki her bir bileşen ile etkileşime gireceği bir model, yüksek sayıda parametreye sahip olacağından az sayıda örnekleme sahip olan çalışmalarda sorun olabilmektedir. Bu sebeple Hipotez 1'de değer uyumu iki yöntemle de gösterildikten sonra Hipotez 2 sadece fark değişkeni kullanma yöntemi ile test edilmiştir. 
ğu iş kaynaklarının pozitif etkilerini göz ardı etmediğini belirtmek gerekmektedir. Aksine, oluşturulan fark değişkeninin doğrudan etkisinin anlamlı bulunması bir anlamda iş kaynağının düşük algılandığı durumda daha düşük işe adanmışlık yaşandığının göstergesidir. İş dış1 zamanlarda katılımcıların bildirdikleri uzmanlaşma aktiviteleri değerlendirmeleri ile kurumun sunduğu gelişim olanaklarına dair algı bildirimlerinin farkı alınarak oluşturulan değişkenin işe adanmışlık üzerinde negatif yönde doğrudan etkisinin bulunması, yüksek uzmanlaşma aktiviteleri bildirip buna karşın kurumda düşük gelişim olanağı algılayan çalışanların daha düşük işe adanmışlık deneyimlediklerini göstermektedir. Bu sonuç, uyumsuzluğu bu yönde yaşamanın daha düşük işe adanmışlık ile ilişkili olduğunu, diğer bir deyişle iş kaynaklarının düşük olduğu bir durumla kendini gösteren değer uyumsuzluğunun işe adanmışlık üzerindeki etkilerinin, uzmanlaşma aktivitelerinin düşük olduğu durum ile kendini gösteren değer uyumsuzluğunun etkisinden daha fazla olabileceği biçiminde yorumlanabilir. Bununla birlikte çalışma sonuçları, iş kaynaklarına dair değer uyumunun işe adanmışlık üzerindeki etkisine vurgu yapmaktadır. İşe adanmışlık üzerindeki değer uyumunun rolünü inceleyen önceki çalışmalardan (Leiter ve Maslach, 2005; Rich ve ark., 2010) farklı olarak bu çalışmadaki değer uyumu kavramı, kuruma dair genel bir değer uyumu olarak değil, belirli bir iş kaynağına özgü değer uyumu olarak kavramsallaştırılmıştır. Anlamlı eğrisel ilişki ise iş kaynaklarının işe adanmışlık üzerindeki etkileri değerlendirilirken çalışanların bu kaynaklara atfettiği değerin de göz önüne alınması gerektiğinin önemini vurgulamaktadır.

Çalışmanın diğer önemli sonucu ise kurumun sunduğu gelişim olanaklarına ilişkin değer uyumunun işe adanmışlık üzerindeki pozitif etkisinin kurumdaki çalışma süresine bağlı olarak değişebileceğidir. Kurumlarda yeni çalışmaya başlamış çalışanlar için değer uyumunun işe adanmışlık üzerinde daha fazla yordayıcı etkiye sahip olduğu saptanmıştır. Yeni çalışanlar değer uyumu deneyimlediklerinde daha tecrübeli çalışma arkadaşları ile benzer işe adanmışlık raporlarken, değer uyumu bildirmedikleri durumda tecrübeli çalışanlara kıyasla daha düşük işe adanmışlık raporlamışlardır.

\section{Çalışmanın Kuramsal ve Uygulamaya Yönelik Katkıları}

Çalışmanın hem iş kaynaklarının işe adanmışlık üzerindeki etkisini inceleyen yazına hem de işe adanmışlığ1 artırmayı hedefleyen uygulamalara yönelik önemli katkıları mevcuttur. İlk olarak çalışma sonuçları daha önce de değinildiği gibi iş kaynaklarının işe adanmışlık ile ilişkisinde değer uyumunun önemini vurgulamaktadır. Çalışma bu yönüyle Leiter ve Maslach'ın (2005) dile getirdiği işe adanmışlığa ilişkin iki model olan İş Talepleri ve Kaynakları Modeli ile Tükenmişliğin ve Adanmışlığın Aracılık Modelini kısmi olarak bir araya getirmektedir. Diğer bir deyişle bu çalışmadan elde edilen sonuçlar iş kaynaklarının işe adanmışlık üzerindeki etkisi araştırılırken değer uyumunun bu kaynaklara ilişkin olarak araştırılmasının da etkili olduğunu göstermiştir. Araştırma iş kaynaklarının işe adanmışlık üzerindeki etkisine bir sınır koşul sunması yönüyle yazına katkı sağlamaktadır ve işe adanmışlık sürecinde değer uyumunun önemini vurgulayan araştırmacılara da destek sunmaktadır (örn., Kahn, 1990). İkinci olarak çalışma, kurumdaki çalışma süresinin iş kaynaklarının değer uyumu ile işe adanmışlık ilişkisinde düzenleyici rol oynadığını göstermiştir. Bu sonuç, belirli bir iş kaynağına ilişkin değer uyumunun ișe adanmışlık üzerindeki ilişkisi incelenirken çalışma süresinin göz önünde bulundurulmasının önemini ortaya koyarak yazına katkı sunmaktadır.

Çalışmanın uygulamaya ve alana da çeşitli katkıları mevcuttur. İlk olarak çalışma bulguları, işe adanmışl1ğ1 artırmaya yönelik iş kaynaklarının belirlenmesi sürecinde, çalışanların sunulacak iş kaynaklarına ne düzeyde önem verdiğinin tespitinin önemine işaret etmektedir. Uygulamacılar iş kaynaklarını çalışanların çoğunluğunun değerleri ile uyumlu biçimde belirleyip uygulamaya geçirirlerse, değer uyumu gözetilmeden belirlenmiş iş kaynaklarına kıyasla daha fazla işe adanmışlık sağlayabilirler. İkinci çıktı ise personel seçim sürecine ilişkindir. Pek çok kurum hali hazırda yerleşmiş bir sisteme sahiptir ve bu durum iş kaynakları için de geçerlidir. Personel seçimi sürecinde uzmanlar, iş kaynaklarına ilişkin değer uyumunu gözeterek çalışanların gelecekteki işe adanmışlık düzeylerini artırmaya yardımcı olabilirler. Örneğin, işe alım mülakatlarında açıkça iş kaynaklarından bahsedilmesi, adaya bunlara yönelik düşüncelerinin sorulması veya bunların bir ölçekle ölçülmesi ve uyuma bakılması sonrası için faydalı olabilir. Çalışmaya ilişkin üçüncü çıkarım, çalışana özgü iş kaynağı sunulmasına ilişkin olabilir. Kurumun sunduğu kişisel gelişim olanaklarında olduğu gibi iş kaynakları her çalışan için aynı düzeyde öneme sahip olmayabilir. $\mathrm{Bu}$ durumda insan kaynakları uzmanları ve yöneticiler çalışanın değerleri ile uyumlu iş kaynaklarını onlar için görünür kılabilirler veya çalışanlara esnek iş kaynakları adı altında öneriler sunarak farklı iş kaynakları içinden kendi değerlerine uygun olanları seçebilmelerini sağlayabilirler. Böylece işe adanmışlık deneyimlerine katkı sağlayabilirler. Dördüncü olarak değer uyumsuzluğuna yol açan çalışan özellikleri çalışan eğitimleri içeriğine dâhil edilebilir. Örneğin, kurumda sunulan kişisel gelişim olanaklarına öneminin farkında olmayan çalışanlar için bu uygulamaların kariyerlerine hangi açılardan faydalı olabileceğine ilişkin sunumlar düzenlenebilir. Böylece değer uyumu 
ve dolayısıyla işe adanmışlığa olumlu katkı sağlanabilir. Bir diğer çıkarım ise iş kaynaklarına ilişkin değer uyumunun özellikle hangi çalışanlar için önemli olduğuna ilişkindir. Çalışma sonuçları kurumdaki çalışma süresi az olan çalışanların değer uyumundan daha fazla etkilendiğini göstermiştir. Bu sebeple kurumda uygulamaya konulacak iş kaynaklarının belirlenmesi ya da eğitim içeriklerinin hazırlanması gibi süreçlerde özellikle kurumdaki çalışma süresi az olan çalışan grubunun bildirimlerine öncelik verilebilir.

Son olarak ise bu araştırmanın Türkiye'de yani farklı bir toplumda ve kültürde yaşayan çalışanlarla yapılmış olmasından söz etmek gerekir. Bu konuyla ilgili birçoğu batıda yapılmış araştırmalar iş kaynaklarının olumlu sonuçları olduğunu göstermiştir (Christian ve ark., 2011). Ancak Batı dışında bir kültürde yaşayan çalışanlarda iş kaynaklarına ilişkin değer uyumunun etkisini araştıran başka bir araştırmaya rastlanmamıştır ve bu araştırma sonuçları bu açıdan da dikkate değerdir.

\section{Çalışmanın Sınırlılıkları ve Gelecekteki Araştırmalar için Öneriler}

Çalışmanın belki de en çarpıcı bulgusu eğer çalışan için değeri düşükse, iş kaynaklarının işe adanmışlık üzerindeki etkisinin azalmasıdır. Bu duruma ilişkin olarak hangi çalışan özelliklerinin bu yönde bir değer uyumsuzluğuna yol açabileceğinin belirlenmesi ya da bu yöndeki değer uyumsuzluğunun neden işe adanmışlığg etkilediği gelecek araştırmaların konusu olabilir. Örneğin gelişim ihtiyac1, zorlu görevlere, başarıya, öğrenmeye ve profesyonel gelişime duyulan ihtiyacı tanımlayan bir kişilik özelliğidir (Hackman ve Oldham, 1976). Gelişim ihtiyacının değer uyumu üzerindeki düzenleyici etkisi, gelecek araştırmaların konusu olabilir. Benzer şekilde varlık öz teorisi ve gelişim öz teorisi de neden bazı çalışanların değer uyumu deneyimlemediğine ve bu uyumsuzluğun işe adanmışlığa olan etkisine ilişkin bir kişilik değişkeni olarak incelenebilir. Varlık öz teorisine sahip kişiler zekâ, yetenek ve beceri gibi özelliklerin doğuştan var olduğuna ve çalışma ve çaba ile geliştirilemeyeceğini düşünürler (Dweck, 1999). Bu zihin yapısına sahip olma, kurumda kişisel gelişim olanaklarına ilişkin iş kaynakları olsa da çalışanın neden bunlardan pozitif yönde etkilenmediğine ve düşük işe adanmışlık raporladığına bir açıklama getirebilir.

Bir diğer önemli nokta ise bu çalışmada kullanılan iş kaynağı olan kurumun sunduğu gelişim olanaklarında olduğu gibi, hangi iş kaynaklarına ilişkin değer uyumunun işe adanmışlığa etkisi olabileceği gelecek araştırmaların konusu olabilir. Leiter ve Bakker (2010) iş kaynaklarının gelişim ve öğrenmeyi destekleyen yönüyle içsel motivasyonu, iş hedeflerini tamamlamayı sağlamaları yönüyle dışsal motivasyonu artırdığını dile getirmişler- dir. İşe adanmışlık kavramındaki yüksek enerji ve özdeşim dikkate alındığında özellikle içsel motivasyonu artıran iş kaynaklarının değer uyumu perspektifinden çalışılmasının fayda sağlayacağı öngörülmektedir. Bu konuya ilişkin Herzberg, Mausner ve Snyderman'in (1959) iki faktör modeli bir temel sunabilir. Modelde güdüleyiciler olarak tanımlanan sorumluluk, profesyonel gelişim gibi iş özelliklerinin motivasyonu artıracağ olarak tanımlanan iş güvencesi, maaş gibi iş özelliklerinin ise motivasyonu artırmayacağı fakat yokluklarının motivasyonu düşüreceği iddia edilmektedir. Model kapsamında güdüleyiciler olarak tanımlanan iş özellikleri, hangi iş kaynaklarının değer uyumu bakış açısıyla çalışılabileceğine ilişkin bir temel oluşturabilir.

Gelecek araştırmalar için bir diğer öneri ise sadece beyaz yakalı çalıșanlar için yürütülmüş olan bu çalışmanın mavi yaka çalışanlar ya da sağlık sektörü çalışanlar1 gibi farklı örneklem gruplarında yapılmasıdır. Değer uyumu işe adanmışlık ilişkisinin farklı örneklem gruplarında test edilmesi kavramlarla ilgili daha çok bilgiye sahip olmamızı sağlayabilir. Son olarak çalışanların finansal tatmin ya da ücretlendirmelerine yönelik algıları gibi faktörlerin incelenmesi de iş kaynaklarına ilişkin değer uyumu ile işe adanmışlık arasındaki ilişkinin dirençli olduğuna yönelik çıkarımlara katkı sağlayacaktır.

Her çalışmada olduğu gibi bu çalışmanın da birtakım sınırlılıkları mevcuttur. İlk olarak çalışmada kullanılan fark değeri biçimde oluşturulan değer uyumu ölçümü, kavramsal anlaşılmazlık ve bilgi kaybı gibi sınırlılıklara sahiptir (Kristof, 1996). Çalışmada bu sınırlılığı aşmak için dolaylı biçimde oluşturulan değer uyumunun etkisi tepki yüzey analiziyle de gösterilse de Kristof'un (1996) belirttiği üzere bu yöntemin de sinırlılıkları mevcuttur. $\mathrm{Bu}$ sebeple sonraki araştırmalar doğrudan uyum ölçümü kullanarak çalışmanın kullanılan uyum yöntemlerine dirençli olup olmadığını sınayabilir. İkinci bir sinırlılık olarak öz bildirime dayalı veri toplama yönteminden söz edilebilir. Bu sınırlılıkla baş etmek için sosyal beğenirlik yanlılığına yatkın bir değişken olan kişisel gelişime verilen değer, davranışa dayalı maddeler ile ölçülmüştür. Gelecekteki çalışmalar öz bildirime dayalı yanlılığı azaltmak için kurumun sunduğu kişisel gelişim olanakları ölçümünü kurum düzey bir değişken olarak ölçümlemeyi tercih edebilirler. Üçüncü olarak çalışmanın kesitsel yapısı nedensel çıkarımlar yapmanın önünde engel oluşturmaktadır. Gelecekteki çalışmalar boylamsal desenlerden faydalanabilirler. Örneğin, yeni işe girmiş çalışanlarla yapılacak boylamsal çalışmalar değer uyum sürecinin işe adanmışlık üzerindeki etkisinin ve kurum uyum sağlama uygulamaları gibi sürece etki edebilecek çeşitli çevresel etkilerin anlaşılmasında aydınlatıcı olacaktır. Son olarak çalıșmanın sonuçlarının tek bir iş kaynağı ile sınırlı olduğunu belirtmek gerekli- 
dir. Sonuçlar iş kaynaklarına ilişkin değer uyumunun işe adanmışlık üzerindeki etkisine bir kanıt sunsa da diğer iş kaynaklarına genelleyebilmek için farklı iş kaynaklarının ve farklı değer uyumu yöntemlerinin kullanıldığ 1 çalışmalara ihtiyaç vardır.

\section{Sonuç}

$\mathrm{Bu}$ araştırma, kurumun sunduğu kişisel gelişim olanakları ile çalışanların bu olanaklara ilişkin değer uyumunun işe adanmışlık üzerinde pozitif yordayıcı bir etkisi olduğunu ortaya koymuştur. Bu bulgu son derece önemlidir çünkü kurumların çalışanlar için oluşturduğu iş kaynaklarından biri olan kişisel gelişim olanaklarının aslında göreceli bir kavram olduğunu ve çalışanların değerleri ile uyumlu olduğu oranda olumlu sonuçları olabileceğini göstermiştir. Bununla birlikte araştırma sonuçları gözlemlenen değer uyumu ile işe adanmışlık ilişkisinin kurumda çalışma süreleri fazla ve az olan çalışanlar arasında da farklılık gösterdiğini göstermiştir. $\mathrm{Bu}$ bilgilerin iş kaynakları ile ișe adanmışlık ilişkisini inceleyen araştırmacılar ve kurumlarındaki çalışanların işe adanmışlık düzeylerini artırmayı hedefleyen uygulamacılar için son derece faydalı olacağı öngörülmektedir.

\section{Kaynaklar}

Babcock-Roberson, M. E. ve Strickland, O. J. (2010). The relationship between charismatic leadership, work engagement, and organizational citizenship behaviors. The Journal of Psychology, 144, 313326. https://doi.org/10.1080/00223981003648336

Bakker, A. B. ve Bal, M. P. (2010). Weekly work engagement and performance: A study among starting teachers. Journal of Occupational and Organizational Psychology, 83, 189-206. https://doi.or$\mathrm{g} / 10.1348 / 096317909 X 402596$

Bakker, A. B. ve Demerouti, E. (2007). The job demands-resources model: State of the art. Journal of Managerial Psychology, 22, 309-328. https://doi. org/10.1108/02683940710733115

Bakker, A. B. ve Demerouti, E. (2017). Job Demands-Resources theory: Taking stock and looking forward. Journal of Occupational Health Psychology, 22, 273-285. http://dx.doi.org/10.1037/ocp0000056

Bakker, A. B., Demerouti, E., Taris, T., Schaufeli, W. B. ve Schreurs, P. (2003). A multi-group analysis of the job demands-resources model in four home-care organizations. International Journal of Stress Management, 10, 16-38. https://doi: 10.1037/1072-5245.10.1.16

Bakker, A. B., Schaufeli, W. B., Leiter, M. P. ve Taris, T. W. (2008). Work engagement: An emerging concept in occupational health psychology. Work \& Stress, 22, 187-200. https://doi. org/10.1080/02678370802393649

Bakker, A. B. ve Xanthopoulou, D. (2009). The crossover of daily work engagement: Test of an actor-partner interdependence model. Journal of Applied Psychology, 94, 1562-1571. http://dx.doi. org/10.1037/a0017525

Bandura, A. (1991). Social cognitive theory of self-regulation. Organizational Behavior and Human Decision Processes, 50, 248-287. https://doi.org/10.1016/0749-5978(91)90022-L

Bartlett, K. R. (2001). The relationship between training and organizational commitment: A study in the health care field. Human Resource Development Quarterly, 12, 335-352. https://doi.org/10.1002/hrdq.1001

Brandstätter, V., Job, V. ve Schulze, B. (2016). Motivational incongruence and well-being at the workplace: Person-job fit, job burnout, and physical symptoms. Frontiers in Psychology, 7, 1153. https://doi. org/10.3389/fpsyg.2016.01153

Belsley, D. A., Kuh, E. ve Welsch, R. E. (1980). Regression diagnostics: Identifying influential data and sources of collinearity. New York: John Wiley \& Sons. 
Bledow, R., Schmitt, A., Frese, M. ve Kühnel, J. (2011). The affective shift model of work engagement. Journal of Applied Psychology, 96, 1246-1257. http://dx.doi.org/10.1037/a0024532

Cable, D. M. ve Judge, T. A. (1997). Interviewers' perceptions of person-organization fit and organizational selection decisions. Journal of Applied Psychology, 82, 546-561. https://doi:10.1037/00219010.82.4.546

Cable, D. M. ve Parsons, C. K. (2001). Socialization tactics and person-organization fit. Personnel Psychology, 54, 1-23. https://doi.org/10.1111/j.1744-6570.2001.tb00083.x

Christian, M. S., Garza, A. S. ve Slaughter, J. E. (2011). Work engagement: A quantitative review and test of its relations with task and contextual performance. Personnel Psychology, 64, 89-136. https://doi. org/10.1111/j.1744-6570.2010.01203.x

Culbertson, S. S., Mills, M. J. ve Fullagar, C. J. (2012). Work engagement and work-family facilitation: Making homes happier through positive affective spillover. Human Relations, 65, 1155-1177. https://doi.org/10.1177/0018726712440295

Deci, E. L. ve Ryan, R. M. (2002). Handbook of self-determination research. Rochester, NY: University of Rochester Press.

Demerouti, E., Bakker, A. B., Nachreiner, F. ve Schaufeli, W. B. (2001). The job demands-resources model of burnout. Journal of Applied Psychology, 86, 499-512. https://doi:10.1037/0021-9010.86.3.499

Dweck, C. S. (1999). Self-theories: Their role in motivation, personality, and development. Philadelphia: Psychology Press.

Dysvik, A. ve Kuvaas, B. (2008). The relationship between perceived training opportunities, work motivation and employee outcomes. International Journal of Training and Development, 12, 138-157. https:// doi.org/10.1111/j.1468-2419.2008.00301.x

Edwards J. R. (1991). Person-job fit: A conceptual integration, literature review and methodological critique. C. L. Cooper ve I. T. Robertson (Ed.) International review of industrial and organizational psychology içinde, (6. Cilt, 283-357). Oxford, United Kingdom: Wiley.

Edwards, J. R. (1994a). Regression analysis as an alternative to difference scores. Journal of Management, 20, 683-689. https://doi. org/10.1177/014920639402000311

Edwards, J. R. (1994b). The study of congruence in organizational behavior research: Critique and a proposed alternative. Organizational Behavior and Human Decision Processes, 58, 51-100. https:// doi.org/10.1006/obhd.1994.1029
Edwards, J. R. (2001). Multidimensional constructs in organizational behavior research: An integrative analytical framework. Organizational Research Methods, 4, 144-192. https://doi. org/10.1177/109442810142004

Edwards, J. R. (2002). Alternatives to difference scores: Polynomial regression analysis and response surface methodology. F. Drasgow ve N. W. Schmitt (Ed.), Advances in measurement and data analysis içinde (350-400). San Francisco: Jossey-Bass.

Edwards, J. R. ve Cable, D. M. (2009). The value of value congruence. Journal of Applied Psychology, 94, 654-677. http://dx.doi.org/10.1037/ a0014891

Edwards, J. R. ve Parry, M. E. (1993). On the use of polynomial regression equations as an alternative to difference scores in organizational research. Academy of Management Journal, 36, 1577-1613. https://doi.org/10.5465/256822

Efron, B. ve Tibshirani, R. (1993). An introduction to the bootstrap. New York: Chapman \& Hall.

Erdogan, B., Kraimer, M. L. ve Liden, R. C. (2004). Work value congruence and intrinsic career success: The compensatory roles of leader-member exchange and perceived organizational support. Personnel Psychology, 57, 305-332. https://doi. org/10.1111/j.1744-6570.2004.tb02493.x

Ery1lmaz, A. ve Doğan, T. (2012). Subjective well-being at work: Investigating of psychometric properties of Utrecht work engagement scale. Journal of Clinical Psychiatry, 15, 49-55.

Hackman, J. R. ve Oldham, G. R. (1976). Motivation through the design of work: Test of a theory. Organizational Behavior and Human Performance, 16, 250-279. https://doi.org/10.1016/00305073(76)90016-7

Hakanen, J. J. ve Roodt, G. (2010). Using the job demands-resources model to predict engagement: Analysing a conceptual model. A. B. Bakker, ve M. P. Leiter (Ed.), Work engagement: A handbook of essential theory and research içinde (85-101). New York: Psychology Press.

Halbesleben, J. R. (2010). A meta-analysis of work engagement: Relationships with burnout, demands, resources, and consequences. A. B. Bakker, ve M. P. Leiter (Ed.), Work engagement: A handbook of essential theory and research içinde (102-117). New York: Psychology Press.

Halbesleben, J. R. ve Wheeler, A. R. (2008). The relative roles of engagement and embeddedness in predicting job performance and intention to leave. Work \& Stress, 22, 242-256. https://doi. org/10.1080/02678370802383962 
Herzberg, F., Mausner, B. ve Snydermann B. (1959). The motivation to work. New York: Wiley.

Ito, J. K. ve Brotheridge, C. M. (2005). Does supporting employees' career adaptability lead to commitment, turnover, or both? Human Resource Management, 44, 5-19. https://doi.org/10.1002/hrm.20037

Kahn, W. A. (1990). Psychological conditions of personal engagement and disengagement at work. Academy of Management Journal, 33, 692-724. https://doi.org/10.5465/256287

Kahn, W. A. (1992). To be fully there: Psychological presence at work. Human relations, 45, 321-349. https://doi.org/10.1177/001872679204500402

Kim, T. Y., Cable, D. M. ve Kim, S. P. (2005). Socialization Tactics, Employee Proactivity, and Person-Organization Fit. Journal of Applied Psychology, 90, 232-241. http://dx.doi.org/10.1037/00219010.90.2.232

Kim, W., Kolb, J. A. ve Kim, T. (2013). The relationship between work engagement and performance: A review of empirical literature and a proposed research agenda. Human Resource Development Review, 12, 248-276. https://doi. org/10.1177/1534484312461635

Knight, C., Patterson, M. ve Dawson, J. (2017). Building work engagement: A systematic review and meta-analysis investigating the effectiveness of work engagement interventions. Journal of Organizational Behavior, 38, 792-812. https://doi. org/10.1002/job. 2167

Koçak, Ö. E. (2013). The moderating effect of self efficacy on the relationship between job resources and work engagement. Yayınlanmamış Yüksek Lisans Tezi, Marmara Üniversitesi, İstanbul.

Koçak, Ö. E. (2017). How employees thrive at work? Importance of relationship quality, person-job fit and recovery experiences after work hours. Yayınlanmamış Doktora Tezi, Marmara Üniversitesi, İstanbul.

Koçak, Ö.E., Agun, H., Günaydın, S.C., Soysal, A., Erebak, S., Karabakkal, H. (2016, 26-28 May1s). Disconnect! If you want to be connected! 15. Ulusal İşletmecilik Kongresi, İstanbul.

Kraimer, M. L., Seibert, S. E., Wayne, S. J., Liden, R. C. ve Bravo, J. (2011). Antecedents and outcomes of organizational support for development: The critical role of career opportunities. Journal of Applied Psychology, 96, 485-500. http://dx.doi. org/10.1037/a0021452

Kristof, A. L. (1996). Person-organization fit: An integrative review of its conceptualizations, measurement, and implications. Personnel Psychology, 49, 1-49. https://doi.org/10.1111/j.1744-6570.1996.tb01790.x
Kristof-Brown, A. L., Zimmerman, R. D. ve Johnson, E. C. (2005). Consequences of individuals' fit at work: A meta-analysis of person-job, person- organization, person- group, and person-superior fit. Personnel Psychology, 58, 281-342. https://doi. org/10.1111/j.1744-6570.2005.00672.x

Leary, M. R. ve Kowalski, R. M. (1990). Impression management: A literature review and two-component model. Psychological Bulletin, 107, 34-47. doi:10.1037/0033-2909.107.1.34

Lee, Y. ve Eissenstat, S. J. (2018). An application of work engagement in the job demands-resources model to career development: Assessing gender differences. Human Resource Development Quarterly, 29, 143-161. https://doi.org/10.1002/hrdq.21310

Leiter, M. P. ve Bakker, A. B. (2010). Work Engagement: Introduction. A. B. Bakker, ve M. P. Leiter (Ed.), Work engagement: A handbook of essential theory and research içinde (1-9) New York: Psychology Press.

Leiter, M. P. ve Maslach, C. (2004). Areas of worklife: A structured approach to organizational predictors of job burnout. P. Perrewè ve D. C. Ganster (Ed.), Research in occupational stress and well being içinde (3. Cilt, 91-134). Oxford, United Kingdom: Elsevier.

Leiter, M. P. ve Maslach, C. (2005). A mediation model of job burnout. A. S. G. Antoniou ve C. L. Cooper (Ed.), Research companion to organizational health psychology içinde (544 -564). Cheltenham, United Kingdom: Edward Elgar.

Leiter, M. P. ve Maslach, C. (2010). Building engagement: The design and evaluation of interventions. A. B. Bakker, ve M. P. Leiter (Ed.), Work engagement: A handbook of essential theory and research içinde (164-180) New York: Psychology Press.

Maslach, C. ve Leiter, M. P. (1997). The truth about burnout: How organizations cause personal stress and what to do about it. San Francisco, CA, US: Jossey-Bass.

Mauno, S., Kinnunen, U. ve Ruokolainen, M. (2007). Job demands and resources as antecedents of work engagement: A longitudinal study. Journal of Vocational Behavior, 70, 149-171. https://doi.org/10.1016/j.jvb.2006.09.002

Reio Jr, T. G. ve Sutton, F. C. (2006). Employer assessment of work-related competencies and workplace adaptation. Human Resource Development Quarterly, 17, 305-324. https://doi.org/10.1002/ hrdq. 1176

Resick, C. J., Baltes, B. B. ve Shantz, C. W. (2007). Person-organization fit and work-related attitudes and decisions: Examining interactive effects with 
job fit and conscientiousness. Journal of Applied Psychology, 92, 1446-1455. http://dx.doi. org/10.1037/0021-9010.92.5.1446

Rich, B. L., Lepine, J. A. ve Crawford, E. R. (2010). Job engagement: Antecedents and effects on job performance. Academy of Management Journal, 53, 617-635. https://doi.org/10.5465/ amj.2010.51468988

Saks, A. M. ve Ashforth, B. E. (1997). Organizational socialization: Making sense of the past and present as a prologue for the future. Journal of Vocational Behavior, 51, 234-279. https://doi.org/10.1006/ jvbe.1997.1614

Salanova, M., Agut, S. ve Peiró, J. M. (2005). Linking organizational resources and work engagement to employee performance and customer loyalty: The mediation of service climate. Journal of Applied Psychology, 90, 1217-1227. http://dx.doi. org/10.1037/0021-9010.90.6.1217

Schaufeli, W. B. ve Bakker, A. B. (2004). Job demands, job resources, and their relationship with burnout and engagement: A multi-sample study. Journal of Organizational Behavior 25, 293-315. https://doi. org/10.1002/job. 248

Schaufeli, W. B., Salanova, M., González-Romá, V. ve Bakker, A. B. (2002). The measurement of engagement and burnout: A two sample confirmatory factor analytic approach. Journal of Happiness Studies, 3, 71-92. https://doi.org/10.1023/A:1015630930326

Schaufeli, W. B., Taris, T. W. ve Van Rhenen, W. (2008). Workaholism, burnout, and work engagement: Three of a kind or three different kinds of employee well-being? Applied Psychology: An International Review, 57, 173-203. https://doi.org/10.1111/ j.1464-0597.2007.00285.x

Schneider, B. (1987). The people make the place. Personnel Psychology, 40, 437-453. https://doi.org/10.1111/j.1744-6570.1987.tb00609.x

Schneider, B., Goldstein, H. W. ve Smith, D. B. (1995). The ASA framework: An update. Personnel Psychology, 48, 747-773. https://doi.org/10.1111/j.1744-6570.1995.tb01780.x

Sonnentag, S. ve Fritz, C. (2007). The Recovery Experience Questionnaire: Development and validation of a measure for assessing recuperation and unwinding from work. Journal of Occupational Health Psychology, 12, 204-221. http://dx.doi. org/10.1037/1076-8998.12.3.204

Verquer, M. L., Beehr, T. A. ve Wagner, S. H. (2003). A meta-analysis of relations between person-organization fit and work attitudes. Journal of Vocational Behavior, 63, 473-489. https://doi.org/10.1016/ S0001-8791(02)00036-2
Vogel, R. M., Rodell, J. B. ve Lynch, J. W. (2016). Engaged and productive misfits: How job crafting and leisure activity mitigate the negative effects of value incongruence. Academy of Management Journal, 59, 1561-1584. https://doi.org/10.5465/ amj.2014.0850

Vohs, K. D. ve Baumeister, R. F. (2004). Understanding self-regulation. R. F. Baumeister ve K. D. Vohs (Ed.), Handbook of self-regulation içinde (1-9). New York, NY: Guilford Press.

Vroom, V. H. (1964). Work and motivation. New York: Wiley. 


\section{Summary}

\section{The Effect of Person Organization Value Congruence Regarding Organizational Opportunities for Personal Development on Work Engagement: Moderating Role of Organizational Tenure}

\author{
Mehmet Peker \\ Ege University
}

\author{
Nevra Cem Ersoy \\ İzmir University of Economics
}

\author{
Muazzez Deniz Giray \\ Independent Researcher
}

Work engagement can be defined as work-related emotional and psychological well-being (Schaufeli, Salanova, González-Romá, \& Bakker, 2002). Studies showed that work engagement is an important construct that is related to higher job performance (Kim, Kolb, \& Kim, 2013), higher organizational citizenship behavior (Halbesleben \& Wheeler, 2008), higher well-being (Schaufeli, Taris, \& Van Rhenen, 2008), and lower intention to leave the organization (Halbesleben \& Wheeler, 2008). Studies investigating work engagement primarily focused on its outcomes, while factors affecting work engagement were relatively understudied (Bledow, Schmitt, Frese, \& Kühnel, 2011). Therefore, this study aims to reveal the effect of a potentially important factor, namely value congruence regarding opportunities for personal development, on work engagement.

Studies have shown that job demands and resources are the most important proximal predictors of work engagement (Bakker \& Bal, 2010; Halbesleben, 2010; Mauno, Kinnunen, \& Ruokolainen, 2007; Schaufeli $\&$ Bakker, 2004). These studies examined the direct links between job demands and resources and work engagement, but only a limited number of studies have yet examined how employees perceived these resources provided by their organizations. Kahn (1990), on the other hand, argued that one of the best predictors of work engagement is the congruence between the values of employees and those of organizations. Hence, it is important to examine how employees perceive the job resources provided for them.

This study focuses on value congruence related to one specific job resource, namely opportunities for personal development. The job demands-resources model and the mediation model of burnout and engagement propose that value congruity is the central factor in explaining employee burnout (Leiter \& Maslach, 2005). According to these models, when the employee's values are in line with the organization's values, employees' motivation and involvement increases; in contrast, when there is divergence, employees feel less engaged in their work (Leiter \& Maslach, 2004). For instance, Rich, Lepine and Crawford (2010) showed that the congruence of employees' and organizations' values was related to employees' work engagement.

Opportunities for personnel development are employees' perceptions about the resources that are provided to them (Kraimer, Seibert, Wayne, Liden, \& Bravo, 2011). Examples of these opportunities are various types of training related to career or personnel development and some types of mentorship. These opportunities are positively related to work motivation and organizational citizenship performance (Bartlett, 2001). In the current study, employees' values were indirectly measured via their recovery activities in leisure time. For this reason, we used the Mastery dimension of the Recovery Experiences Scale. This dimension is composed of items such as "attending foreign language courses" and "learning new hobbies". Because opportunities for personal development and mastery dimensions are conceptually similar, we focused on the congruency of these two constructs. Value congruency takes place when the organization provides opportunities for personal development and the employee engages in mastery activities outside of work, or when the organization does not provide opportunities for personal development and the employee does not engage in mastery experiences in leisure time. On the other hand, value discrepancy implies either that the employee engages in mastery experiences but the organization does not provide opportunities for personal development, or that the employee does not engage in mastery activities while the organization provides opportunities for personal development. The same type of conceptualization of value congruence was examined before. Brandstätter, Job, and Schulze (2016) investigated the degree of misfit between motivational

Address for Correspondence: Res. Asst. Mehmet Peker, Ege University, Faculty of Letters, Department of Psychology 35040 Bornova / İzmir E-mail: mehmet.peker@ege.edu.tr 
needs and supplies, showing that the fit between personal needs and environmental supplies influences burnout and physical symptoms. Theories and previous studies claim that value congruence is an important predictor of work engagement (e.g., Kahn, 1990; Leiter \& Bakker, 2010). In other words, in addition to the existence of opportunities, the experience of value congruence related to personal development is expected to be positively related to employees' work engagement.

Hypothesis 1: There is a curvilinear relationship between value congruence regarding opportunities for personal development and work engagement.

Similar to individuals, organizations also have sets of values, shaped by their management and employees. Beginning from the attraction stage, organizations seek employees whose values are in alignment with theirs. Similarly, job applicants are also inclined to choose organizations that share their values (Resick, Baltes, \& Shantz, 2007). After recruitment, employees' values may be shaped by organizations through various processes, such as employee orientation or socialization. As employees' tenure increases, their values become even more similar to those of their organizations. Attractionselection-attrition model (Schneider, 1987) also describes this process. The model asserts that job applicants are attracted to and prefer organizations with which they share values; similarly, organizations are likely to recruit employees whose values align with theirs; and lastly, employees who are not able to align their values with their organizations' tend to leave. Based on these arguments, we assert that the effects of value congruence regarding opportunities for personal development will be more similar for high tenure employees compared to their newly recruited counterparts.

According to attraction-selection attrition model (Schneider, 1987), job applicants seek organizations that hold similar values with their own and organizations want to hire employees who share similar values with theirs. However, other factors may influence this process in an opposite way. For example, job applicants may use impression management tactics by displaying values they do not actually share with the organizations (Leary \& Kowalski, 1990). Such factors may bring about low value congruence between employees and organizations. Although some studies show that value incongruence has a negative relationship with work engagement (Rich et al., 2010), there might be some factors influencing the association between value incongruence and work engagement. For example, Erdogan, Kraimer, and Liden (2004) showed that leader-member exchange and perceived organization support attenuated the negative effects of value incongruence on job and career satisfaction. Vogel, Rodell, and Lynch (2016) showed that job crafting acted as a buffer in the employee work engagement and value incongruence relationship. Employees experience positive practices and adapt to their work context over time. Hence, employee tenure is an important factor that determines adaptation to a certain work environment (Reio \& Sutton, 2006; Saks \& Ashforth, 1997). In light of these, the following hypothesis was generated:

Hypothesis 2: Tenure will moderate the curvilinear relationship between value congruence regarding opportunities for personal development and work engagement. Specifically, the curve will be steeper for newly recruited employees.

\section{Method}

\section{Participants}

The sample consists of 204 employees (102 women and $102 \mathrm{men}$ ) employed in different sectors, such as service, finance, and construction, in İzmir. The mean age of participants was 36.1 years $(S D=8.7)$. More than half had bachelor's degree $(60 \%)$. The mean tenure of employees was 6.9 years $(S D=6.4)$.

\section{Measures}

Utrecht Work Engagement Scale (UWES). The 17-item original version of Utrecht Work Engagement Scale (Schaufeli et al., 2002) which was adapted to Turkish by Ery1lmaz and Doğan (2012) was used to measure work engagement. The scale includes three dimensions, namely vigor, dedication, and absorption. Items were scored on a scale ranging from (1) "strongly disagree" to (5) "strongly agree". High scores on all three dimensions indicated high work engagement. Internal consistencies (Cronbach's alpha) for the vigor, dedication, and absorption scales were $.87, .87$, and .84, respectively.

Recovery Experience Scale. The Recovery Experience Scale is a 16-item instrument developed by Sonnentag and Fritz (2007) and aims to assess psychological detachment, relaxation, mastery, and control. This scale was adapted to Turkish by Koçak et al. (2016) and reviewed by Koçak (2017). In the current study, only the 4-item mastery dimension was used. Typical examples of mastery experiences include taking a language class or learning a new hobby, which refer to off-the-job activities. Responses were obtained on a 5-point Likert-type scale that varied between (1) "I do not agree at all" and (5) "I fully agree". The Cronbach's alpha of mastery dimension was .86.

Job Resources. Opportunities for personal development were measured with the 3-item scale developed by Bakker, Demerouti, Taris, Schaufeli, 
and Schreurs (2003) and adapted to Turkish by Koçak (2013). The items refer to opportunities for personal development provided at work. Items were scored on a scale ranging from (1) "strongly agree" to (6) "strongly disagree". Cronbach's alpha was .88 .

\section{Results}

Prior to the main analyses, a confirmatory factor analysis was performed to ensure that the measurements were distinct constructs. The results showed that after removing item 15 and releasing four error covariances between the items in the Work Engagement Scale, the model provided acceptable fit to the data, $\chi^{2}(222, N=$ $204)=411.17, p<.001$, RMSEA $=.07, \mathrm{TLI}=.90, \mathrm{CFI}$ $=.91$.

As outliers are specifically influential in polynomial regression and response surface analyses, Cook's distance and leverage values of participants were examined, and 10 outliers were removed. Hypothesis 1 asserted a curvilinear relationship between value congruence and work engagement. The difference score between mastery experience of employees and organizational opportunities for personal development was computed prior to analyses. After controlling for age and gender, results showed that value congruence $(\beta$ $=-.18, p<.011)$ and value congruence squared $(\beta=-.32$, $p<.001)$ were significantly related to work engagement.

In order to overcome the disadvantages related to the use of distance scores in value measurements (Edwards, 1994a, 2001; Kristof, 1996), response surface analysis was implemented based on the equation given below ${ }^{1}$ : $b_{5} \mathrm{ME}^{2}+e$

$\mathrm{WE}=b_{0}+b_{1} \mathrm{OD}+b_{2} \mathrm{ME}+b_{3} \mathrm{OD}^{2}+b_{4} \mathrm{OD} \times \mathrm{ME}+$

The results showed that the interaction term (opportunities for personal development $\times$ mastery experiences) was significant, which provided initial support for Hypothesis 1 . In the second step, the sum of $b_{3}$ $-b_{4}+b_{5}$ was found to be significantly different than zero, and in the third step 10000 bootstrap resamples were generated to estimate whether the confidence intervals of the slope included 1 and the confidence intervals of the intercept included 0 . The results supported the expectations. In the last step, the sums of $b_{3}+b_{4}+b_{5}$ and $b_{1}+b_{2}$ were found to be not significantly different than zero. Overall, these results provided support for Hypothesis 1.

Hypothesis 2 proposed that the curvilinear relationship between value congruence related to opportunities for personal development and work engagement is moderated by employee tenure. The interaction term produced by multiplying value congruence squared and tenure was significantly related to work engagement $(\beta=.22, p=.016)$, which provided support for Hypothesis 2.

\section{Discussion}

The study results showed that in addition to the job resources provided by organizations, congruence of value attributed to those resources by employees is important in explaining work engagement. Moreover, the findings also showed that the influence of value congruence on work engagement is more pronounced for newly recruited employees. The findings of this study have important implications for both theory and practice. First of all, study findings suggest that conceptualizing value congruence as a job resource-specific construct has potential to contribute to research. Secondly, results also confirm the claims of the attraction-selectionattrition model in explaining the influence of tenure on the relationship between value congruence and work engagement. Practitioners may also benefit from the findings of this study. In order to foster work engagement, they may consider the value attributed to a specific job resource by employees. Secondly, in the personnel selection process, they can seek a match between the values of employees and those of the organization to increase potential work engagement levels. Lastly, the findings also imply that newly recruited employees might be prioritized as they were found to be more adversely influenced by value incongruence compared to employees with longer tenure.

Future studies can contribute to this study's findings in several directions. First of all, revealing the factors that cause value incongruence may be beneficial. In this regard, growth need strength and growth mindset have potential to explain why some but not all employees attribute value to the opportunities for personal development provided by their organization. Secondly, revealing value congruence related to which job resources have positive relationship with work engagement may contribute to the research in this area. We propose that job resources specified as "motivators" in Herzberg, Mausner, and Snyderman's (1959) twofactor model may be especially prone to the influence of value congruence.

As in any study, this study has several limitations. First, use of difference scores to conceptualize value congruence has several disadvantages (Kristof, 1996). Future studies may investigate value congruence by endorsing a different methodology. Secondly, self-report measures have their drawbacks. This study tried to avoid

1 WE: work engagement, OD: Opportunities for personal development, ME: mastery experiences. 
this bias by constructing an indirect measure of value congruence, but future research can adopt a different strategy by using aggregate measures of job resources and test whether the same findings are observed.

In conclusion, this study stresses the importance of value congruence related to a specific job resource in explaining the effects of job resources on work engagement. In addition to the studies that documented the positive influence of job resources on work engagement, this study further suggests that considering employees' value congruence related to the job resources may have its merits, especially for newly recruited employees. 